\title{
A Critical Role for Astrocytes in Hypercapnic Vasodilation in Brain
}

\author{
[Clare Howarth, ${ }^{1,2,4 *}$ Brad A. Sutherland, ${ }^{3 *}{ }^{-}$Hyun B. Choi, ${ }^{1}$ CChris Martin, ${ }^{2,4}$ Barbara Lykke Lind, ${ }^{5}$ \\ @Lila Khennouf, ${ }^{5}$ Jeffrey M. LeDue, ${ }^{1}{ }^{\circ}$ Janelle M.P. Pakan, ${ }^{1}{ }^{\circ}$ Rebecca W.Y. Ko, ${ }^{1}$ Graham Ellis-Davies, ${ }^{6}$ \\ (D) Martin Lauritzen, ${ }^{5,7}$ Nicola R. Sibson, ${ }^{2}$ Alastair M. Buchan, ${ }^{3}$ and Brian A. MacVicar ${ }^{1}$ \\ ${ }^{1}$ Djavad Mowafaghian Centre for Brain Health, University of British Columbia, Vancouver, British Columbia V6T 1Z3, Canada, ${ }^{2}$ Cancer Research United \\ Kingdom and Medical Research Council Oxford Institute for Radiation Oncology, Department of Oncology, University of Oxford, Oxford, OX3 7DQ, United \\ Kingdom, ${ }^{3}$ Acute Stroke Programme, Radcliffe Department of Medicine, University of Oxford, Oxford, OX3 9DU, United Kingdom, ${ }^{4}$ Department of \\ Psychology, University of Sheffield, Sheffield, S10 2TP, United Kingdom, ${ }^{5}$ Department of Neuroscience and Pharmacology and Center for Healthy Aging, \\ University of Copenhagen, DK-2200 Copenhagen N, Denmark, ${ }^{6}$ Department of Neuroscience, Mount Sinai School of Medicine, New York, New York 10028, \\ and ${ }^{7}$ Department of Clinical Neurophysiology, Rigshospitalet, DK-2600 Glostrup, Denmark
}

Cerebral blood flow (CBF) is controlled by arterial blood pressure, arterial $\mathrm{CO}_{2}$, arterial $\mathrm{O}_{2}$, and brain activity and is largely constant in the awake state. Although small changes in arterial $\mathrm{CO}_{2}$ are particularly potent to change $\mathrm{CBF}\left(1 \mathrm{mmHg}\right.$ variation in arterial $\mathrm{CO}_{2}$ changes $\mathrm{CBF}$ by $3 \%-4 \%)$, the coupling mechanism is incompletely understood. We tested the hypothesis that astrocytic prostaglandin $\mathrm{E}_{2}\left(\mathrm{PgE}_{2}\right)$ plays a key role for cerebrovascular $\mathrm{CO}_{2}$ reactivity, and that preserved synthesis of glutathione is essential for the full development of this response. We combined two-photon imaging microscopy in brain slices with in vivo work in rats and C57BL/6J mice to examine the hemodynamic responses to $\mathrm{CO}_{2}$ and somatosensory stimulation before and after inhibition of astrocytic glutathione and $\mathrm{PgE}_{2}$ synthesis. We demonstrate that hypercapnia (increased $\mathrm{CO}_{2}$ ) evokes an increase in astrocyte $\left[\mathrm{Ca}^{2+}\right]_{\mathrm{i}}$ and stimulates COX-1 activity. The enzyme downstream of COX-1 that synthesizes $\mathrm{PgE}_{2}$ (microsomal prostaglandin E synthase-1) depends critically for its vasodilator activity on the level of glutathione in the brain. We show that, when glutathione levels are reduced, astrocyte calcium-evoked release of $\mathrm{PgE}_{2}$ is decreased and vasodilation triggered by increased astrocyte $\left[\mathrm{Ca}^{2+}\right]_{\mathrm{i}}$ in vitro and by hypercapnia in vivo is inhibited. Astrocyte synthetic pathways, dependent on glutathione, are involved in cerebrovascular reactivity to $\mathrm{CO}_{2}$. Reductions in glutathione levels in aging, stroke, or schizophrenia could lead to dysfunctional regulation of CBF and subsequent neuronal damage.

Key words: astrocyte; calcium; cerebral blood flow; glutathione; hypercapnia

Significance Statement

Neuronal activity leads to the generation of $\mathrm{CO}_{2}$, which has previously been shown to evoke cerebral blood flow $(\mathrm{CBF})$ increases via the release of the vasodilator $\mathrm{PgE}_{2}$. We demonstrate that hypercapnia (increased $\mathrm{CO}_{2}$ ) evokes increases in astrocyte calcium signaling, which in turn stimulates COX-1 activity and generates downstream $\mathrm{PgE}_{2}$ production. We demonstrate that astrocyte calcium-evoked production of the vasodilator $\mathrm{PgE}_{2}$ is critically dependent on brain levels of the antioxidant glutathione. These data suggest a novel role for astrocytes in the regulation of $\mathrm{CO}_{2}$-evoked CBF responses. Furthermore, these results suggest that depleted glutathione levels, which occur in aging and stroke, will give rise to dysfunctional CBF regulation and may result in subsequent neuronal damage.

\section{Introduction}

Astrocyte $\left[\mathrm{Ca}^{2+}\right]_{\mathrm{i}}$ transients have been shown to directly alter diameters of cerebral arterioles in experiments using either direct

Received Jan. 1, 2016; revised Nov. 21, 2016; accepted Dec. 14, 2016.

Author contributions: C.H., B.S., H.B.C., C.M., B.L.L., G.E.-D., M.L., N.R.S., A.M.B., and B.A.M. designed research; C.H., B.S., H.B.C., C.M., B.L.L., L.K., J.M.P.P., R.K., and G.E.-D. performed research; C.H., B.S., H.B.C., C.M., B.L.L., L.K., J.M.L., and R.K. analyzed data; C.H., B.S., H.B.C., C.M., B.L.L., M.L., N.R.S., A.M.B., and B.A.M. wrote the paper. astrocyte stimulation or calcium uncaging in astrocytes of juvenile (Zonta et al., 2003; Mulligan and MacVicar, 2004; Gordon et

This work was supported by a Sir Henry Wellcome Post-Doctoral Fellowship to C.H., a Government of Canada Post-Doctoral Research Fellowship to C.H., a Michael Smith Foundation for Health Research Post-Doctoral Fellowship to C.H., a Natural Sciences and Engineering Research Council Post-Doctoral Fellowship to J.M.P.P., a Canadian Institutes of Health Research Doctoral Studentship to R.K., a Canada Research Chair in Neuroscience to B.A.M. Canadian Institutes of Health Research Operating Grants 148397, 8545, 115121, and TCE-117869 in the framework of the ERA-NET NEURON to B.A.M., Fondation Leducq to B.A.M., A.M.B., and M.L., Human Frontiers Science Program to B.A.M. and G.E.-D., National Institutes of Health Grants GM053395 and NS069720 to G.E.-D., Heart and Stroke 
al., 2008), or adult animals (Takano et al., 2006). However, several laboratories have published contradictory evidence on whether, in adult animals, astrocyte $\left[\mathrm{Ca}^{2+}\right]_{i}$ signaling is evoked by synaptic activity leading to neurovascular coupling (Zonta et al., 2003; Petzold et al., 2008; Schulz et al., 2012; Lind et al., 2013; Otsu et al., 2015) or not (Nizar et al., 2013; Takata et al., 2013; Bonder and McCarthy, 2014). More recently, astrocyte $\left[\mathrm{Ca}^{2+}\right]_{\mathrm{i}}$ was shown to modify basal arteriole tone in adult animals (Rosenegger et al., 2015). Therefore, it is still poorly understood when, how, and under what conditions, astrocyte $\left[\mathrm{Ca}^{2+}\right]_{i}$ signaling contributes to the regulation of cerebral blood flow (CBF).

In this work, we investigated the mechanisms underlying $\mathrm{CBF}$ responses to increased blood $\mathrm{CO}_{2}$ concentrations (hypercapnia) and the potential contribution of astrocytes to those CBF responses. Arterial $\mathrm{CO}_{2}$ has a potent effect on $\mathrm{CBF}$, with a $1 \mathrm{mmHg}$ variation eliciting a 3\%-4\% CBF change (Hauge et al., 1980). However, the mechanism coupling a change in $\mathrm{CO}_{2}$ to a change in $\mathrm{CBF}$ is incompletely understood. There are parallels between the vasoactive signals generated by astrocytes and those underlying hypercapnia-evoked CBF responses. Astrocytes have been shown to directly modify arteriole diameter when their intracellular $\left[\mathrm{Ca}^{2+}\right]_{\mathrm{i}}$ increases, activating astrocytic phospholipase $\mathrm{A}_{2}$ $\left(\mathrm{PLA}_{2}\right)$ (He et al., 2012) and thereby generating arachidonic acid (AA) and several vasoactive metabolites including $\mathrm{PgE}_{2}$, which causes vasodilation (Zonta et al., 2003; Takano et al., 2006; Gordon et al., 2008; Attwell et al., 2010). In addition to their roles in neurovascular coupling, both $\mathrm{PgE}_{2}$ (Wagerle and Mishra, 1988; Wagerle and Degiulio, 1994) and cyclooxygenase-1 (COX-1) activity (Niwa et al., 2001) are involved in increasing CBF during hypercapnia. We examined the potential link between astrocytes and increased $\mathrm{CBF}$ during hypercapnia because astrocytes express the enzymes that are involved in synthesizing $\mathrm{PgE}_{2}$ from $\mathrm{AA}$ during hypercapnia-induced CBF changes (Niwa et al., 2001). For example, mRNA for both COX-1 and microsomal prostaglandin E synthase-1 (mPgES-1) are reported in transcriptome studies to be highly expressed in astrocytes but not neurons (e.g., ptgs1, also known as COX-1, is 15-fold higher in astrocytes than in neurons) (Cahoy et al., 2008; Zhang et al., 2014). Astrocytes are immunoreactive for both the enzyme proteins COX-1 (Takano et al., 2006; Gordon et al., 2008) and mPgES-1 (see Fig. $3 \mathrm{~A}$ and Tachikawa et al., 2012). mPgES-1, the form of prostaglandin E synthase expressed in astrocytes, requires the cofactor glutathione (GSH) (Jakobsson et al., 1999; Murakami et al., 2000) that is present in high levels in astrocytes (see Fig. $3 B$ and Sun et al., 2006; Bragin et al., 2010; Robillard et al., 2011). We investigated whether hypercapnia can evoke an increase in astrocyte $\left[\mathrm{Ca}^{2+}\right]_{\mathrm{i}}$ in vivo and, if so, whether this results in activation of a $\mathrm{PgE}_{2}$ mediated vasodilation. In doing so, we demonstrate a novel,

Foundation to B.A.M. and H.B.C., the Wellcome Trust to C.M., Royal Society University Research Fellowship to C.M., Cancer Research United Kingdom C5255/A12678 to N.R.S., the Henry Smith Charity to A.M.B., NORDEA Foundation for the Center for Healthy Aging to M.L., the Lundbeck Foundation to M.L., the NOVO-Nordisk Foundation to M.L., and the Danish Medical Research Council to M.L. We thank David Attwell for discussions regarding this work.

The authors declare no competing financial interests.

${ }^{*}$ C.H. and B.S. contributed equally to this work.

Correspondence should be addressed to either of the following: Dr. Brian A. MacVicar, Djavad Mowafaghian Centre for Brain Health, 2215 Wesbrook Mall, University of British Columbia, Vancouver, British Columbia V6T 1Z3, Canada, E-mail: bmacvicar@brain.ubc.ca; or Dr. Alastair M. Buchan, Acute Stroke Programme, Radcliffe Department of Medicine, University of 0xford, 0xford, OX3 9DU, United Kingdom, E-mail: alastair.buchan@medsci.ox.ac.uk.

B. Sutherland's present address: School of Medicine, University of Tasmania, Hobart, Australia.

DOI:10.1523/JNEUROSCI.0005-16.2016

Copyright (c) 2017 Howarth, Sutherland et al.

This is an open-access article distributed under the terms of the Creative Commons Attribution License Creative Commons Attribution 4.0 International, which permits unrestricted use, distribution and reproduction in any medium provided that the original work is properly attributed.
GSH-dependent mechanism of CBF regulation, which involves astrocytes and the GSH-sensitive release of $\mathrm{PgE}_{2}$.

\section{Materials and Methods}

\section{Slice preparation}

Four hundred $\mu \mathrm{m}$ hippocampal-neocortical slices were prepared from male and female juvenile ( postnatal age 16-21 d) Sprague Dawley rats. Treatment of animals was approved by the University of British Columbia Animal Care and Use Committee. As previously described (Gordon et al., 2008), rats were anesthetized with halothane, decapitated, and the brains removed into ice-cold slicing solution containing the following (in mM): $2.5 \mathrm{KCl}, 26 \mathrm{NaHCO}_{3}, 0.5 \mathrm{CaCl}_{2}, 10 \mathrm{MgSO}_{4}, 1.25 \mathrm{NaH}_{2} \mathrm{PO}_{4}, 10$ glucose, 230 sucrose, saturated with $95 \% \mathrm{O}_{2} / 5 \% \mathrm{CO}_{2}$. The $400 \mu \mathrm{m}$ transverse hemi-sections were incubated at $32^{\circ} \mathrm{C}-34^{\circ} \mathrm{C}$ in aCSF containing the following (in mM): $126 \mathrm{NaCl}, 2.5 \mathrm{KCl}, 26 \mathrm{NaHCO}_{3}, 2.0 \mathrm{CaCl}_{2}, 2.0 \mathrm{MgCl}_{2}$, $1.25 \mathrm{NaH}_{2} \mathrm{PO}_{4}, 10$ glucose, saturated with $95 \% \mathrm{O}_{2} / 5 \% \mathrm{CO}_{2}$ for $60 \mathrm{~min}$. For experiments, slices were at $22^{\circ} \mathrm{C}-24^{\circ} \mathrm{C}$, aCSF was saturated with $20 \%$ $\mathrm{O}_{2} / 5 \% \mathrm{CO}_{2}$, balanced $\mathrm{N}_{2}$, and perfused at $\sim 2 \mathrm{ml} / \mathrm{min}$. Healthy slices can be maintained in $20 \% \mathrm{O}_{2}$, which provides a $\mathrm{pO}_{2}$ at the low end of the physiological range (Gordon et al., 2008). Astrocytes were loaded with the caged $\mathrm{IP}_{3}$ compound, NV-IP $3 / \mathrm{AM}(5 \mu \mathrm{g} / \mathrm{ml})$, and/or the $\mathrm{Ca}^{2+}$ indicator rhod-2/AM $(10 \mu \mathrm{M}$, Invitrogen) as previously described (Mulligan and MacVicar, 2004; Gordon et al., 2008). Slices were loaded with monochlorobimane (MCB, Fluka) in the dark at room temperature for $30 \mathrm{~min}$ as previously described (Robillard et al., 2011).

\section{Two-photon imaging and uncaging in acute brain slices}

A two-photon laser-scanning microscope (Zeiss LSM510-Axioskop-2 fitted with a $40 \times-W / 1.0$ numerical aperture objective lens) coupled to a Chameleon ultra II Ti:sapphire laser ( $\sim 140$ fs pulses $80 \mathrm{MHz}$, Coherent) provided excitation of rhod- 2 and was used to uncage $\mathrm{IP}_{3}$. Images were acquired 50-100 $\mu \mathrm{m}$ below the slice surface. Rhod-2 fluorescence imaging and two-photon uncaging were performed using laser settings and emission filters as previously described (Gordon et al., 2008). MCB was excited at $780 \mathrm{~nm}$ and detected with a PMT at $512-562 \mathrm{~nm}$ as previously described (Robillard et al., 2011). Arterioles (defined as vessels with diameter $>10 \mu \mathrm{m}$, surrounded by a visible layer of smooth muscle cells) were imaged by acquiring the transmitted laser light and using IR-DIC optics.

\section{Glutathione and $\mathrm{PgE} \mathrm{E}_{2}$ measurements}

Protocols in suppliers' instructions were followed for the $\mathrm{PgE}_{2}$ ELISA and glutathione assays. When measuring $\mathrm{PgE}_{2}$ release from acute brain slices, TTX ( $1 \mu \mathrm{M}$, Alamone Labs) was added to dampen neuronal activation. $\mathrm{PgE}_{2}$ release from acute brain slices was measured using a Specific $\mathrm{Pa}-$ rameter $\mathrm{PgE}_{2}$ ELISA kit (R\&D systems). Measurements of tissue glutathione levels were made using a specific total glutathione assay kit from either BioVision or Assay Designs.

\section{Immunohistochemistry}

Rats were anesthetized with halothane, given an intraperitoneal injection of urethane $(0.5 \mathrm{ml}$ of $30 \%$ urethane per $50 \mathrm{~g}$ body weight $)$, and perfused with saline $(0.9 \% \mathrm{NaCl}$ in $0.1 \mathrm{M}$ phosphate buffer) followed by $4 \%$ PFA (in $0.1 \mathrm{~m}$ PBS). The brain was extracted, postfixed (10\% sucrose in $4 \%$ PFA) overnight, and cryoprotected (30\% sucrose in PBS) overnight. Using a cryostat, $40 \mu \mathrm{m}$ serial sections in the horizontal plane were collected throughout the brain. Free-floating sections were blocked with $10 \%$ normal goat serum (Jackson ImmunoResearch Laboratories) and $0.4 \%$ Triton X-100 in PBS for $1 \mathrm{~h}$ and incubated in PBS containing 0.1\% Triton $\mathrm{X}-100$ and primary antibodies against $\mathrm{PgE}_{2}$ synthase (anti-mPgES-1) (Olajide et al., 2014; Tuure et al., 2015) (Agrisera, catalog \#AS03 031, 1:200) as well as an astrocyte phenotypic marker (anti-GFAP (Lathia et al., 2008) (Sigma, catalog \#G3893, clone \#G-A-5, 1:500) overnight at $4^{\circ} \mathrm{C}$. Tissue was rinsed and incubated in AlexaFluor- 488 goat anti-mouse and AlexaFluor-546 goat anti-rabbit secondary antibodies (Invitrogen: diluted 1:500 in PBS, 2.5\% normal goat serum and $0.4 \%$ Triton $\mathrm{X}-100$ ) for $1.5 \mathrm{~h}$ at room temperature. The tissue was rinsed, mounted onto slides, and coverslipped using Fluorsave mounting medium 
Table 1. Blood gases for BSO experiment (Nota Bene blood gases taken $24 \mathrm{~h}$ after drug but before hypercapnia and whisker stimulation experiments) ${ }^{a}$

\begin{tabular}{llll}
\hline Treatment & $\mathrm{pH}$ & $\mathrm{pCO}_{2}(\mathrm{mmHg})$ & $\mathrm{pO}_{2}(\mathrm{mmHg})$ \\
\hline Saline & $7.47(0.01)$ & $34.5(2.3)$ & $161(4)$ \\
$\mathrm{BSO}^{b}$ & $7.46(0.01)$ & $35.8(1.5)$ & $154(7)$ \\
\hline
\end{tabular}

${ }^{a}$ Data are mean (SEM).

${ }^{b}$ An inhibitor of $\gamma$-glutamylcysteine synthetase.

(Calbiochem). Images were acquired with an Olympus Fluoview FV1000 confocal microscope.

\section{Drugs}

trans-ACPD (tACPD), clonidine, norepinephrine (NE; Sigma), and $\mathrm{PgE}_{2}$ (Cayman Chemicals) were bath applied for 5-10 min. SC560 (Sigma) was preincubated for $30 \mathrm{~min}$ (Blanco et al., 2008) followed by bath application and buthionine sulfoximine (BSO; Sigma) was preincubated for $2.5 \mathrm{~h}$ (Sun et al., 2006) followed by bath application throughout the experiment. NV-IP 3 /AM was synthesized by G. Ellis-Davies.

Animals: in vivo blood flow measurements in rats

All procedures were approved by the University of Oxford Ethical Review Committee and complied with the requirements of the Animals (Scientific Procedures) Act, 1986, United Kingdom. Animals were housed in an animal housing facility in a $12 \mathrm{~h}$ alternating light:dark cycle with ad libitum access to food and water. Male Wistar rats were used (256-367 g).

\section{Intracerebral injection}

For surgical procedures, rats were anesthetized with $4 \%$ isoflurane and maintained at $1.5 \%-2 \%$ isoflurane in $30 \% \mathrm{O}_{2}$ and $70 \% \mathrm{~N}_{2}$. Each rat was placed in a stereotaxic frame and the skull exposed. A burr hole was drilled at $1 \mathrm{~mm}$ caudal and $4.2 \mathrm{~mm}$ lateral to bregma, and the dura mater was finely dissected away to expose the cortex. Twenty $\mu \mathrm{lof} 80 \mathrm{mg} / \mathrm{ml}$ BSO (Pileblad and Magnusson, 1989) or $0.9 \%$ saline was infused by a microinfusion pump at a rate of $2 \mu \mathrm{l} / \mathrm{min}$ into the right whisker barrel cortex at a depth of $2.3 \mathrm{~mm}$ from the brain's surface. This dose of BSO has previously been shown to adequately reduce GSH within $24 \mathrm{~h}$ of administration (Pileblad and Magnusson, 1989), and we showed that BSO administered in this way could decrease GSH levels in the ipsilateral cortex by $45 \%, 24 \mathrm{~h}$ after injection (see Fig. $5 \mathrm{C}$ ), and in the ipsilateral striatum by $31 \%$ (GSH measured in saline-treated: $0.61 \pm 0.03 \mathrm{mM}$, BSO-treated: $0.42 \pm 0.08 \mathrm{mM}, p=0.045, n=7$ per group, mean \pm SEM). After the infusion, bone wax was placed over the burr hole and the wound was closed with 3-0 sutures. Animals recovered for $24 \mathrm{~h}$ before assessment of GSH levels ( $n=7$ per group) or evoked blood flow responses $(n=6-10$ per group).

\section{Whisker pad stimulation and hypercapnia: in vivo blood} flow measurements

At $24 \mathrm{~h}$ after BSO/saline treatment, animals had their left femoral artery cannulated for blood gas measurement and were tracheotomized and ventilated with $1.25 \%$ isoflurane in $30 \% \mathrm{O}_{2}$ and $70 \% \mathrm{~N}_{2}$. A laser Doppler probe (Perimed) to monitor relative $\mathrm{CBF}$ was placed over the right whisker barrel cortex (where the intracerebral injection was made) and bipolar stimulating electrodes were placed in the left whisker pad. For some experiments, a local field potential (LFP) electrode for neuronal activity was also placed on the exposed cortex to monitor neuronal activity. All animals had a steady-state blood gas (Table 1) before beginning experiments.

An electrical stimulus $(10 \mathrm{~Hz}, 16 \mathrm{~s}$ duration, $1.6 \mathrm{~mA}, 0.3 \mathrm{~ms}$ pulsewidth, $60 \mathrm{~s}$ interstimulation interval) to evoke a blood flow response in the right whisker barrel cortex was performed for 10 trials per animal. Following this, animals were exposed to $10 \% \mathrm{CO}_{2}$ for $30 \mathrm{~s}$ at $3 \mathrm{~min}$ intervals repeated 4 or 5 times to induce hypercapnic blood flow responses. Animals were killed and the cortex dissected for measurement of GSH levels.

For SC560 experiments, naive rats were anesthetized with isoflurane. Anesthesia was induced with $4 \%$ isoflurane and maintained during surgery with $2 \%$ isoflurane. During stimulation, anesthesia was maintained with $1.25 \%$ isoflurane. Isoflurane was carried in $30 \% \mathrm{O}_{2}$ and $70 \% \mathrm{~N}_{2}$.
Table 2. Blood gases for $\mathrm{SC} 560$ intravenous experiment (Nota Bene blood gases taken before and after drug administration $)^{a}$

\begin{tabular}{lllll}
\hline Condition & Treatment & $\mathrm{pH}$ & $\mathrm{pCO}_{2}(\mathrm{mmHg})$ & $\mathrm{pO}_{2}(\mathrm{mmHg})$ \\
\hline Predrug & DMSO & $7.47(0.01)$ & $33.5(1.5)$ & $164(5)$ \\
& $\mathrm{SC5} 60$ & $7.45(0.01)$ & $36.8(1.2)$ & $140(5)$ \\
Postdrug & $\mathrm{DMSO}$ & $7.46(0.01)$ & $34.1(0.6)$ & $156(6)$ \\
& $\mathrm{SC560}$ & $7.45(0.03)$ & $37.1(2.1)$ & $140(5)$ \\
\hline
\end{tabular}

${ }^{a}$ Data are mean (SEM).

Rats had their left femoral artery and vein cannulated, and were also tracheotomized and ventilated. A laser speckle camera (Moor Instruments) was used to monitor relative CBF over a thin skull window over the right whisker barrel cortex while an LFP electrode for neuronal activity was inserted through a burr hole. Bipolar stimulating electrodes were placed in the left whisker pad. Animals had a steady-state blood gas before and after drug administration (Table 2). An electrical stimulus (10 $\mathrm{Hz}, 16 \mathrm{~s}$ duration, $1.6 \mathrm{~mA}, 0.3 \mathrm{~ms}$ pulsewidth, $60 \mathrm{~s}$ interstimulation interval) to evoke a blood flow response in the right whisker barrel cortex was performed for 10 trials per animal. Following this, animals were exposed to $10 \% \mathrm{CO}_{2}$ for $30 \mathrm{~s}$ at $3 \mathrm{~min}$ intervals repeated four times to induce a hypercapnic blood flow response. Animals were then administered $5 \mathrm{mg} / \mathrm{kg}$ SC560 or 10\% DMSO (vehicle) intravenously. SC560 is a highly lipophilic COX-1 inhibitor and distributes widely into tissues (Teng et al., 2003), and this dose was chosen for maximal target efficiency (Zhang et al., 2003). After 20 min, the effect of COX-1 inhibition on the evoked CBF responses to whisker stimulation and hypercapnia was measured.

\section{Animals: in vivo calcium imaging}

For in vivo experiments, all procedures involving animals were approved by the Danish National Ethics Committee according to the guidelines set forth in the European Council's Convention for the Protection of Vertebrate Animals used for Experimental and Other Scientific Purposes. The 8- to 10-week-old male C57BL/6J mice were used.

\section{In vivo calcium imaging}

For experiments involving mice, anesthesia was induced with bolus injections of the $\alpha 2$-adrenergic receptor agonist xylazine $(10 \mathrm{mg} / \mathrm{kg}$ i.p.) and the NMDA-receptor antagonist ketamine $(60 \mathrm{mg} / \mathrm{kg}$ i.p.). Anesthesia was maintained during surgery with supplemental doses of ketamine (30 mg/kg/20 min i.p.). Upon completion of all surgical procedures, anesthesia was switched to continuous infusion with $\alpha$-chloralose (50 mg/kg/h i.v.).

Calcium activity during hypercapnia was measured in vivo in eight C57BL/6J mice. A craniotomy over the somatosensory cortex was covered with agarose and partly sealed with a glass coverslip. Oregon Green Bapta-1/AM (OGB; Invitrogen) was dissolved in DMSO and Pluronic F-127 (10\%, BASF Global) and diluted in aCSF to yield a final dye concentration of $0.8 \mathrm{~mm}$. It was mixed with the astrocyte marker sulforhodamine 101 (SR101; Sigma-Aldrich, $100 \mu \mathrm{M}$ ) (Nimmerjahn et al., 2004) and was pressure injected (4-6 psi, $4 \mathrm{~s}$ ) into the somatosensory cortex through a micropipette at a depth of $100-150 \mu \mathrm{m}$ below the cortical surface. $\mathrm{Ca}^{2+}$ imaging was performed using a commercial two-photon microscope (SP5 multiphoton/confocal Laser Scanning Microscope; Leica), and a Mai Tai HP Ti:sapphire laser (Millennia Pro, Spectra Physics) with a $20 \times 1.0 \mathrm{NA}$-water-immersion objective (Leica). The excitation wavelength was $820 \mathrm{~nm}$. The emitted light was filtered to retain both red and green light using a TRITC/FITC filter.

The hypercapnia challenge was presented as follows: Following $1 \mathrm{~min}$ baseline recording, $10 \% \mathrm{CO}_{2}$ in air was applied for $30 \mathrm{~s}$ and imaging continued for subsequent $4 \mathrm{~min}$. Five trials were performed with $3 \mathrm{~min}$ between trials. For each animal, a second field of view was selected and the hypercapnia challenge repeated. Blood gases were taken after each experiment, and all mice had $\mathrm{pCO}_{2}$ in the range $30-40 \mathrm{mmHg}$ and $\mathrm{pO}_{2}$ in the range $95-130 \mathrm{mmHg}$.

\section{Data collection, analysis, and statistics}

In vitro data. An image $(512 \times 512$ pixels $)$ was collected in $7.86-12.68 \mathrm{~s}$, using 8-line averaging. Measurements of lumen diameter and $\mathrm{Ca}^{2+}$ 
changes were performed offline with Zeiss LSM (version 3.2) software and ImageJ (National Institutes of Health). As previously described (Gordon et al., 2008), fluorescence signals were defined as $F / F_{0}(\%)=$ $\left[\left(F_{1}-B_{1}\right) /\left(F_{0}-B_{0}\right)\right] 100$, where $F_{1}$ and $F_{0}$ are fluorescence at a given time and the mean fluorescence during the control period, respectively. $B_{1}$ and $B_{0}$ are the corresponding background fluorescence signals, taken from the neuropil. Pseudo-color images show absolute changes in fluorescence (ImageJ, 16-color linear Lut). Experimental values are mean \pm $\mathrm{SEM} ; n$ is the number of experiments conducted or, for calcium changes, number of astrocytes analyzed. Either a two-tailed Student's $t$ test or a one-way ANOVA with a Newman-Keuls post hoc test for comparison between multiple groups was used, and $p<0.05$ was considered statistically significant. As these were novel experiments, the effect size was unknown before the experiment. Therefore, sample size estimates were based on our previous experience. Experiments were alternately performed under control or treatment conditions with slices chosen at random for each experiment. Data were excluded from analysis if any of the following occurred during imaging: unstable baseline vessel diameters or astrocyte calcium levels, or movement leading to significant focus changes during the experiment. To perform statistical analysis, data were assumed to be normally distributed.

In vivo data. All laser Doppler and LFP data were collected in Spike 2 software, whereas laser speckle data were collected using Moor FLPI software. Quantification of CBF changes and electrophysiology were performed in MATLAB (The MathWorks, version 7.12). To obtain the region of interest (ROI) for calculation of $\mathrm{CBF}$ changes using laser speckle imaging, a principal components analysis was used to identify the focal point of the change in response to stimulation. The same region of interest was used within each animal's data. Experimental values are the mean \pm SEM, and $n$ is the number of animals. To perform statistical analysis, data were assumed to be normally distributed. An $F$ test was used to compare variances of groups being statistically compared. For CBF data, a one-tailed $t$ test with Welch's correction (as groups had significantly different variances) was used to compare means between groups. A two-tailed $t$ test was used to compare means of groups for both GSH analysis (see Fig. 5C) and electrophysiology data in response to whisker pad stimulation (Welch-corrected for SC560 experiment, see Fig. 6C). For electrophysiology data collected during hypercapnia challenge experiments, a two-way ANOVA with Bonferroni correction for multiple comparisons was used to compare means between groups. $p<$ 0.05 was considered statistically significant. For experiments involving rats, due to effect sizes being unknown before experiment, sample size estimates were based on previously published sample sizes (e.g., Niwa et al., 2001). Assignment of animals was alternated between treatment and control groups, and neither experiments nor analysis were blinded. Three animals were excluded from all data analysis ( 1 for SC560 and 2 for $\mathrm{BSO})$ due to technical problems with experimental equipment.

For in vivo calcium imaging, frame size was $256 \times 256$ pixels (189-207 $\mathrm{ms}$ /frame) during recordings. The $\mathrm{Ca}^{2+}$ changes were evaluated as the average change in fluorescence relative to baseline levels in ROIs. The ROIs were placed based on morphology over neuronal or astrocytic soma, or neuropil. Because of movement of astrocytes during hypercapnia, within or out of focus, ROIs were evaluated based on the level of SR101 loading in the red channel. If a significant change occurred, the ROI was disregarded in all following assessments. An increase in fluorescence within an ROI was classified as a calcium response if the mean fluorescence value within the period of hypercapnia was $>2$ SDs of baseline activity. The delay of the $\mathrm{Ca}^{2+}$ response was found by subtracting the signal onset time from the time hypercapnia was introduced to the animal. To estimate response start and termination time, a fit was made to the data and the first- and second-order derivatives were calculated. The response onset time was found by taking the maximum peak of the second order derivative of the fitted data. The duration of the $\mathrm{Ca}^{2+}$ response was then found by subtracting the response onset time from the response termination time. The response termination time was defined as the time point when the fitted data went below mean baseline $\mathrm{Ca}^{2+}$ levels or the recording ended. Experimental values are expressed as mean \pm SEM. A paired $t$ test was used for the calcium imaging data, each animal served as its own control. $p<0.05$ was accepted as statistically significant. For experiments involving mice, as there have been no previous studies reporting astroglial calcium changes during hypercapnia, it was impossible to estimate an expected value for change in fluorescence or its SD. Hence, no sample size calculation could be performed. However, we expected similar calcium changes to those we observe for lowfrequency whisker stimulation, and so sample sizes were based on our previous experiments (6-8 mice). Calcium signals obtained during hypercapnia exceeded an SNR of 4:1, and hypercapnia-induced calcium responses were recorded in every animal tested. As all mice were subjected to hypercapnia, there was no randomization method used. Control measurements of calcium activity (i.e., activity without application of hypercapnia) were taken at random time points during the experiment. Analysis of calcium changes was not blinded, assessment of these changes was based on a MATLAB program, which analyzes the image sequences in an unbiased manner, rather than by visual inspection.

\section{Results}

Increased $\mathrm{CO}_{2}$ evokes $\left[\mathrm{Ca}^{2+}\right]_{\mathrm{i}}$ responses in astrocytes in vivo Elevation of tissue $\mathrm{CO}_{2}$ concentration, which can be caused by neuronal metabolism, is known to dilate cerebral blood vessels in a process dependent on $\mathrm{PgE}_{2}$ (Wagerle and Mishra, 1988; Wagerle and Degiulio, 1994) formation via COX-1 activity (Niwa et al., 2001). However, the cells that both are responsible for sensing $\mathrm{CO}_{2}$ and that also express the enzymes for synthesizing $\mathrm{PgE}_{2}$ (COX-1 and PgES) have not been resolved. Astrocytes can produce $\mathrm{PgE}_{2}$, but it is unknown whether astrocytes generate $\left[\mathrm{Ca}^{2+}\right]_{\mathrm{i}}$ signals in response to $\mathrm{CO}_{2}$. Therefore, we tested whether an increase in inspired $\mathrm{CO}_{2}$ (hypercapnia) in vivo evokes astrocyte $\left[\mathrm{Ca}^{2+}\right]_{\mathrm{i}}$ when it also triggers CBF increases.

Two-photon laser scanning microscopy (2PLSM) in vivo was used to examine the simultaneous responses of both neurons and astrocytes to hypercapnia in the intact brain as a first step to investigate which cell type might be the primary sensor of $\mathrm{CO}_{2}$ (Fig. 1). Remarkably, we found consistent and significant increases in $\left[\mathrm{Ca}^{2+}\right]_{\mathrm{i}}$ in the soma and endfeet of astrocytes in cortical layers II/III of mouse (Fig. 1) during the period of hypercapnia. The dramatic increases that we observed in astrocytes were of significantly higher amplitude (Fig. $1 A-C$; $p<0.01$ ) than increases in $\left[\mathrm{Ca}^{2+}\right]_{\mathrm{i}}$ observed in neuronal soma during the period of hypercapnia. The number of astrocytes with $\left[\mathrm{Ca}^{2+}\right]_{\mathrm{i}}$ responses was also much greater in hypercapnia compared with the number showing spontaneous calcium activity (control time period: Fig. $1 D ; p<0.01$ ). Although neurons could display increased $\left[\mathrm{Ca}^{2+}\right]_{\mathrm{i}}$ during hypercapnia, with onset times within seconds (Fig. $1 B, C, E$ ), there was no significant difference in the number of neurons with $\left[\mathrm{Ca}^{2+}\right]_{\mathrm{i}}$ responses during hypercapnia compared with the number showing spontaneous calcium activity (control time period: Fig. 1D). Measurements taken in the neuropil where there were no defined cell bodies, and it is difficult to separate signals in fine astrocyte processes from neuronal processes did not show correlated changes in $\left[\mathrm{Ca}^{2+}\right]_{\mathrm{i}}$ signals during hypercapnia (Fig. $1 D$ ). The astrocyte $\left[\mathrm{Ca}^{2+}\right]_{\mathrm{i}}$ responses (Fig. $\left.1 B, E, F\right)$ appear to occur within a similar timescale as the increased $\mathrm{CBF}$ evoked by hypercapnia (as measured by laser speckle contrast imaging and laser Doppler flowmetry in rat; see Fig. $5 A, D$, respectively). During hypercapnia, an increased number of astrocyte soma (Fig. 1D) displayed increased $\left[\mathrm{Ca}^{2+}\right]_{\mathrm{i}}$ with onsets within seconds (Fig. $1 B, E$ ) and variable durations of tens of seconds (Fig. $1 B, F$ ). While there were no differences between the three groups (astrocyte soma, neuronal soma, and neuropil) with regards to the delay of the hypercapnia-induced $\mathrm{Ca}^{2+}$ responses (average $\mathrm{Ca}^{2+}$ response delay [Fig. $1 E$ ]: neuron soma $=12.14 \pm$ $1.19 \mathrm{~s}(n=33)$, neuropil $=12.83 \pm 4.18 \mathrm{~s}(n=3)$, and astrocyte soma $=14.57 \pm 1.55 \mathrm{~s}(n=47))$, the average $\mathrm{Ca}^{2+}$ response 

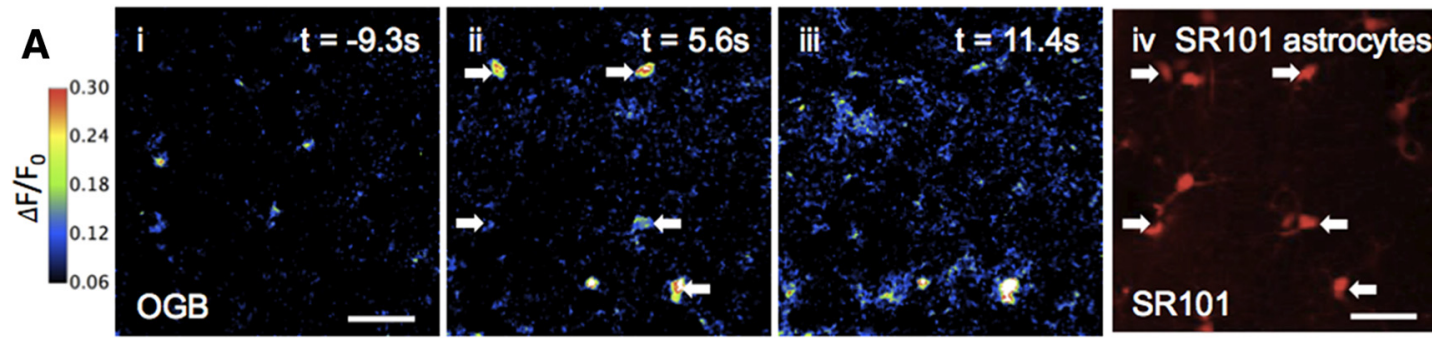

B i
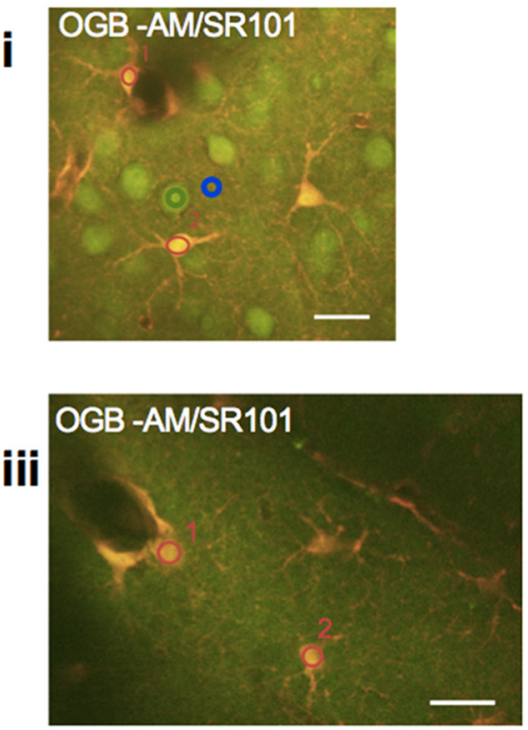

C

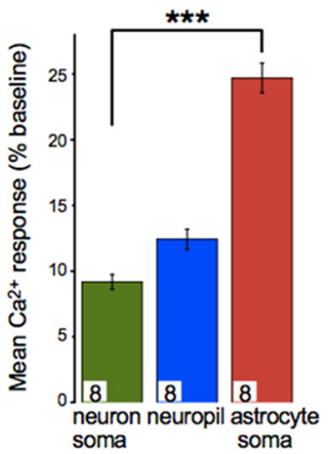

E

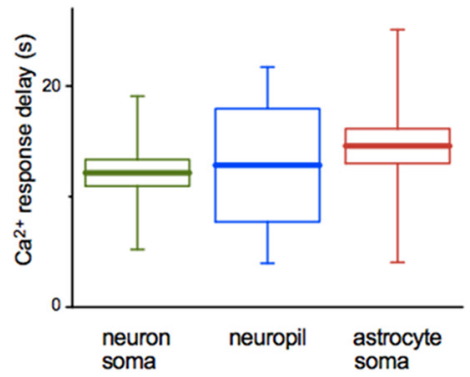

ii
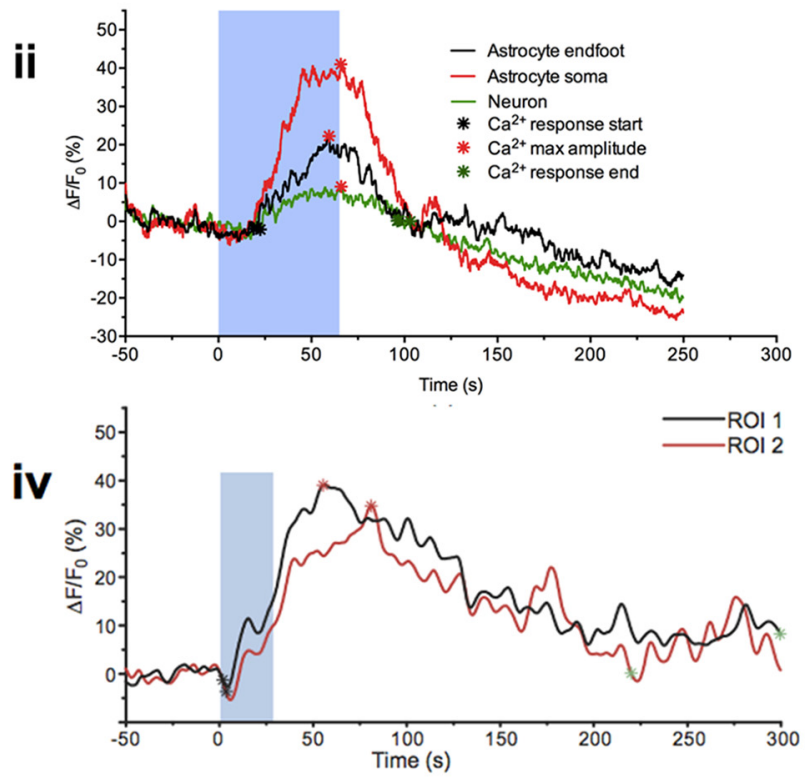

D

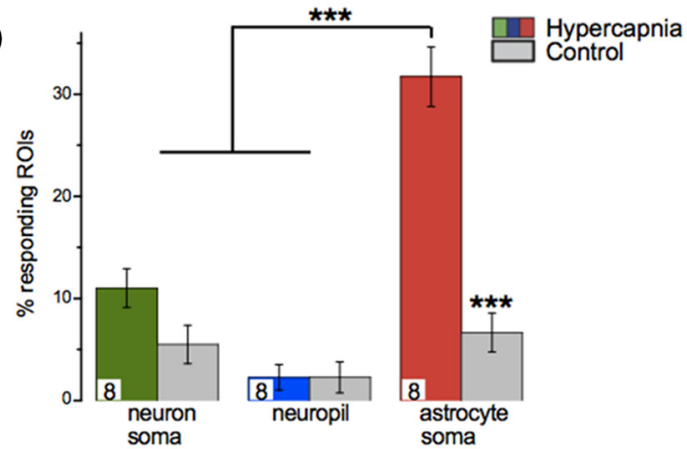

$\mathbf{F}$

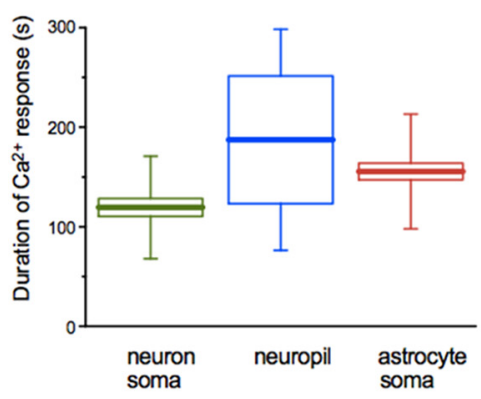

Figure 1. Astrocyte $\left[\mathrm{Ca}^{2+}\right]_{\mathrm{i}}$ transients are evoked by $\mathrm{CO}_{2}$ in vivo.A, Example still images of mouse cortical layer I/IIIIfrom 2PLSM. OGB is used as a calcium indicator (Ai-Aiii) and sulforhodamine 101 (SR101, Aiv, average image for whole recording) is used to stain astrocytes. Color scale refers to images Ai-Aiii. White arrows indicate astrocytes that show a $\mathrm{Ca}^{2+}$ response to $\mathrm{CO}_{2}$ of at least twice its baseline $\mathrm{Ca}^{2+}$ fluctuation. In this case, $\mathrm{CO}_{2}$ stimulus begins at $t=0$ s and is applied for $36 \mathrm{~s}$. Aiii, Recovery of immediate $\mathrm{CO}_{2}$ induced $\mathrm{Ca}^{2+}$ transient. Scale bars, $40 \mu \mathrm{m}$. Bi, Biii, Further example images of mouse cortical layer II/III from 2PLSM showing example ROI placement. Merge images showing OGB and SR101 (Bi, Biii). Red R011 indicates astrocyte endfoot. Red R012 indicates astrocyte soma (layer Il: $n=181,8$ mice). Green ROl indicates neuron soma (layer Il: $n=153,8$ mice). Blue ROl indicates neuropil (layer Il: $n=104,8$ mice). Scale bar, $20 \mu$ m. Example time series (Bii, Biv) of [Ca $\left.{ }^{2+}\right]_{i}$ response in astrocyte and neuron soma ROIs (as indicated in Bi, Biiti). Blue box represents time during which expired $\mathrm{CO}_{2}$ level is increased. C, Mean Ca ${ }^{2+}$ response in ROls. Colors represent ROls located as shown in Bi. D, Percentage of ROls for each cell type that showed a $\mathrm{Ca}^{2+}$ response with and without a hypercapnia stimulus. For no hypercapnia (control), $n=170$ astrocyte somas, $n=148$ neuronal soma, and $n=96$ neuropil ROls, $n=8$ mice. Colors represent description in $\boldsymbol{B}$. E, Delay from hypercapnia start time to start of $\mathrm{Ca}^{2+}$ response in $\mathrm{ROl}$. $\boldsymbol{F}$, Duration of $\mathrm{Ca}^{2+}$ response in each $\mathrm{RO}$ in response to $\mathrm{CO}_{2}$ stimulus. $\boldsymbol{E}, \boldsymbol{F}, \mathrm{Box}$ plots represent the mean $(\mathrm{small}$ square). Edges of the box represent $25 \%$ and $75 \%$ of data. End lines indicate maximum and minimum values. Data are mean \pm SEM. ${ }^{* *} p<0.01 .{ }^{* * *} p<0.001$. 


\section{tACPD-evoked $\left[\mathrm{Ca}^{2+}\right]_{i}$ responses are unaffected by decreased $\mathrm{GSH}$ levels although $\mathrm{PgE}_{2}$ release is decreased}

A
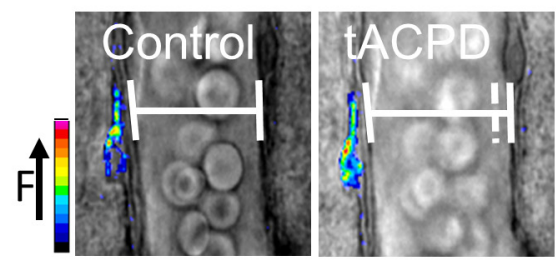

B

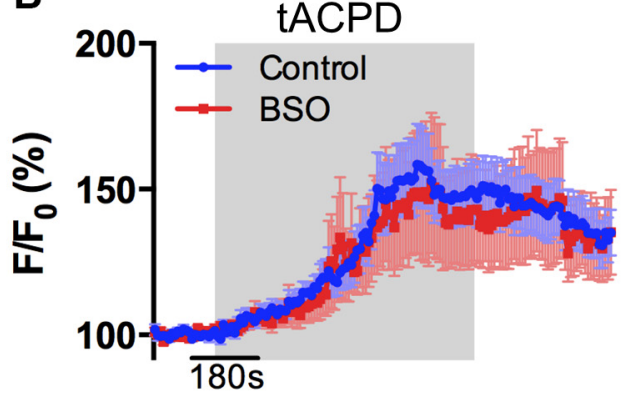

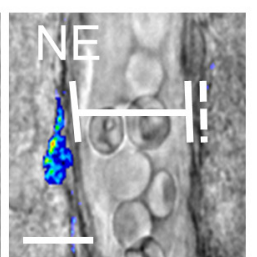
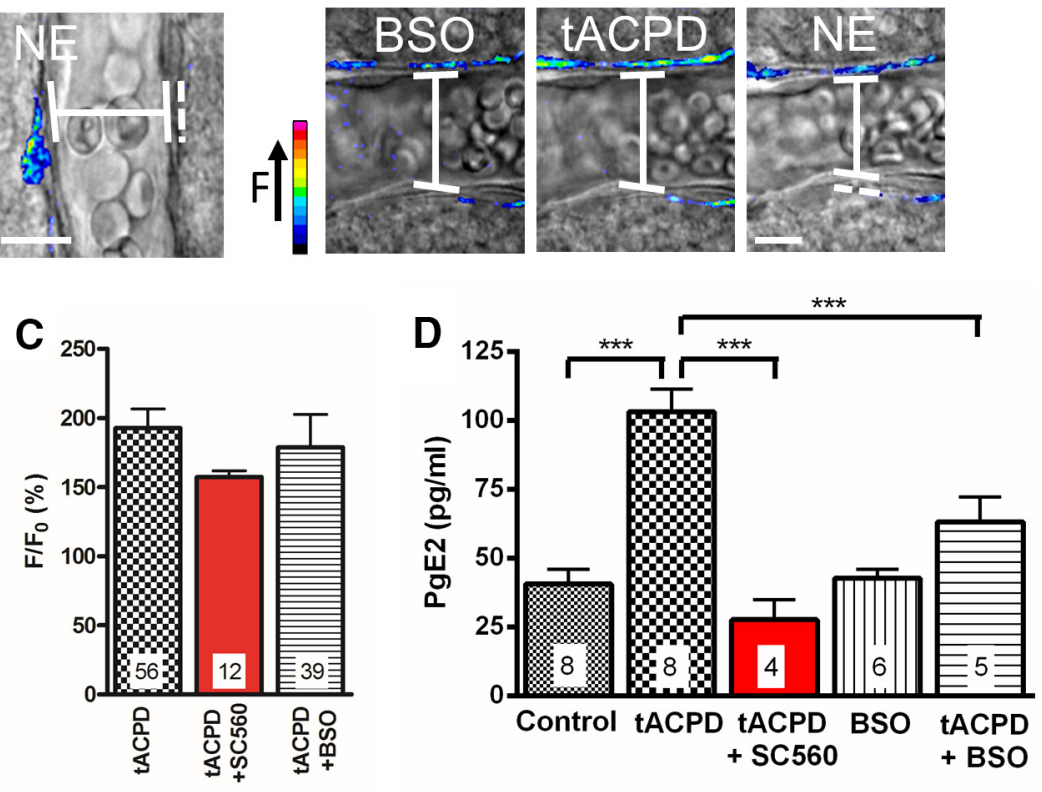

\section{tACPD-evoked COX-1 and GSH-dependent vasodilations in brain slices}
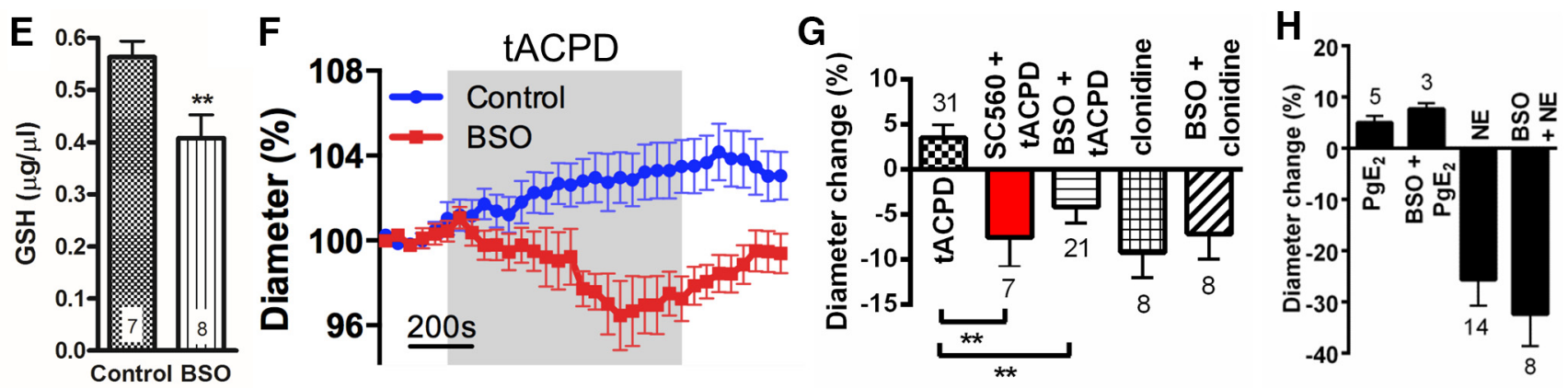

Figure 2. Astrocyte $\left[\mathrm{Ca}^{2+}\right]_{\mathrm{i}}$ signals evoke COX-1- and GSH-dependent vasodilations in vitro. A, 2PLSM imaging: example $\mathrm{Ca}^{2+}$ and arteriole diameter changes in response to tACPD with and without BSO. Images represent overlay of pseudo-colored $\mathrm{Ca}^{2+}$ changes and transmitted light images. Dotted line indicates initial vessel diameter. Scale bar, $10 \mu \mathrm{m} . \boldsymbol{B}$, Mean time course of increase in astrocyte $\left[\mathrm{Ca}^{2+}\right]_{\mathrm{i}}$ in response to $\mathrm{ACPD}$. Colored box represents time of tACPD application. Control, $n=56$ from 26 rats; BSO, $n=39$ from 18 rats. C, Mean tACPD-evoked increase in astrocyte $\left[\mathrm{Ca}^{2+}\right]_{\mathrm{i}}$ t tACPD, $n=56$ from 26 rats; tACPD + SC560, $n=12$ from 7 rats; tACPD + BSO,$n=39$ from 18 rats. $D$, Mean tACPD-evoked PgE 2 release, measured by ELISA. Within a group, each experiment $(n)$ uses tissue from a different rat (i.e., control, $n=8$ from 8 rats). $\boldsymbol{E}$, Mean tissue GSH concentration; data from 4 rats for each group. $F$, Mean time course of tACPD-evoked change in lumen diameter. Colored box represents time of tACPD application. Control, $n=31$ slices from 26 rats; BSO, $n=21$ slices from 18 rats. $G$, Mean changes in lumen diameter evoked by tACPD and clonidine. $\mathrm{tACPD}, n=31$ slices from 26 rats; $\mathrm{SC} 560+\mathrm{tACPD}, n=7$ slices from 7 rats; $\mathrm{BSO}+\mathrm{tACPD}, n=21$ slices from 18 rats; clonidine, $n=8$ slices from 8 rats; $\mathrm{BSO}+$ clonidine, $n=8$ slices from 7 rats. $\boldsymbol{H}$, Mean changes in lumen diameter evoked by $\mathrm{PgE}_{2}$ and $\mathrm{NE}^{\mathrm{PgE}}, n=5$ lices from 4 rats; $\mathrm{BSO}+\mathrm{PgE}_{2}, n=3$ slices from 3 rats; $\mathrm{NE}, n=14$ slices from 11 rats; $\mathrm{BSO}+\mathrm{NE}, n=8$ slices from 7 rats. Data are mean $\pm S E M .{ }^{* *} p<0.01 .{ }^{* * *} p<0.001$. n, number of experiments conducted or, for calcium measurements, number of astrocyte ROls analyzed.

duration (Fig. $1 F$ ) was found to be significantly longer in astrocytes than in neurons: neuron soma $=119.41 \pm 8.82 \mathrm{~s}(n=33)$, astrocyte soma $=155.47 \pm 8.32 \mathrm{~s}(n=47)(p<0.05$, ANOVA $)$.

Astrocytic $\left[\mathrm{Ca}^{2+}\right]_{\mathrm{i}}$ signals evoke subsequent GSH-dependent $\mathrm{PgE}_{2}$ release

Having demonstrated in vivo that hypercapnia evokes an increase in astrocyte $\left[\mathrm{Ca}^{2+}\right]_{\mathrm{i}}$, we then used a combination of 2PLSM and $\mathrm{PgE}_{2}$ measurements using ELISA in acute brain slices to determine the mechanistic links between astrocyte $\left[\mathrm{Ca}^{2+}\right]_{i}$ responses and $\mathrm{CBF}$ regulation. Using a biochemical model, we investigated the role of GSH in the generation of $\mathrm{PgE}_{2}$.

Unlike in the in vivo situation, it is difficult to reliably evoke astrocyte $\left[\mathrm{Ca}^{2+}\right]_{\mathrm{i}}$ signals and vasodilations by applying $\mathrm{CO}_{2}$ to acute brain slices. Thus, we needed an alternative method of elevating astrocyte $\left[\mathrm{Ca}^{2+}\right]_{\mathrm{i}}$ in acute brain slices. Although the adult mouse (Sun et al., 2013) and rat (Duffy and MacVicar, 1995) have been shown to not express functional mGluR5, bath application of the mGluR agonist tACPD is known to increase astrocyte $\left[\mathrm{Ca}^{2+}\right]_{\mathrm{i}}$ in younger animals (Mulligan and MacVicar, 2004). Therefore, tACPD was used to evoke reliable, reproducible astrocyte $\left[\mathrm{Ca}^{2+}\right]_{\mathrm{i}}$ elevations in acute brain slices from juvenile rats. To evoke widespread increases in astrocyte $\left[\mathrm{Ca}^{2+}\right]_{i}$, hippocampalneocortical slices were perfused with tACPD, an mGluR agonist. Application of tACPD $(100 \mu \mathrm{M})$ to brain slices (from juvenile rats) caused a generalized increase in astrocyte $\left[\mathrm{Ca}^{2+}\right]_{\mathrm{i}}$, observed 
A

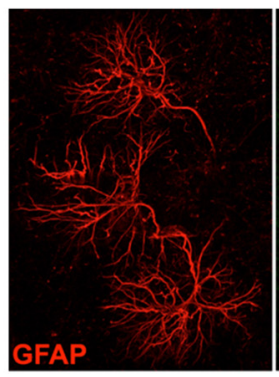

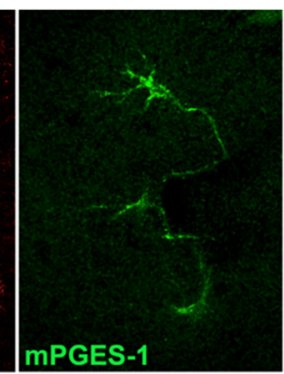

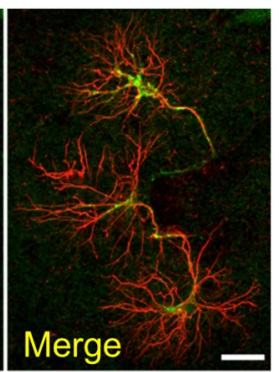

B

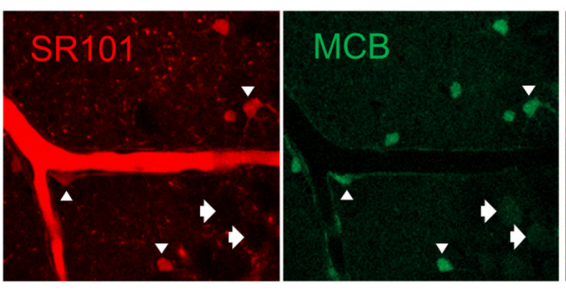

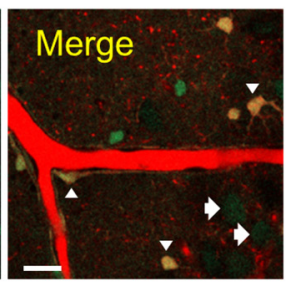

Figure 3. Astrocytes express mPGES-1 and contain high levels of GSH. $\boldsymbol{A}$, Immunohistochemistry showing astrocytic expression of GSH-dependent mPGES-1 in the CA3 of the hippocampus. Astrocyte marker, GFAP (red), mPGES-1 (green), and merge (yellow). Scale bar, $20 \mu \mathrm{m}$. B, MCB-loaded hippocampal-neocortical slices. Astrocytes (identified by SR101, red, white arrowheads) contain higher levels of GSH (as indicated by MCB staining, green) than neurons (white arrows). Merge (yellow). Scale bar, $20 \mu \mathrm{m}$.

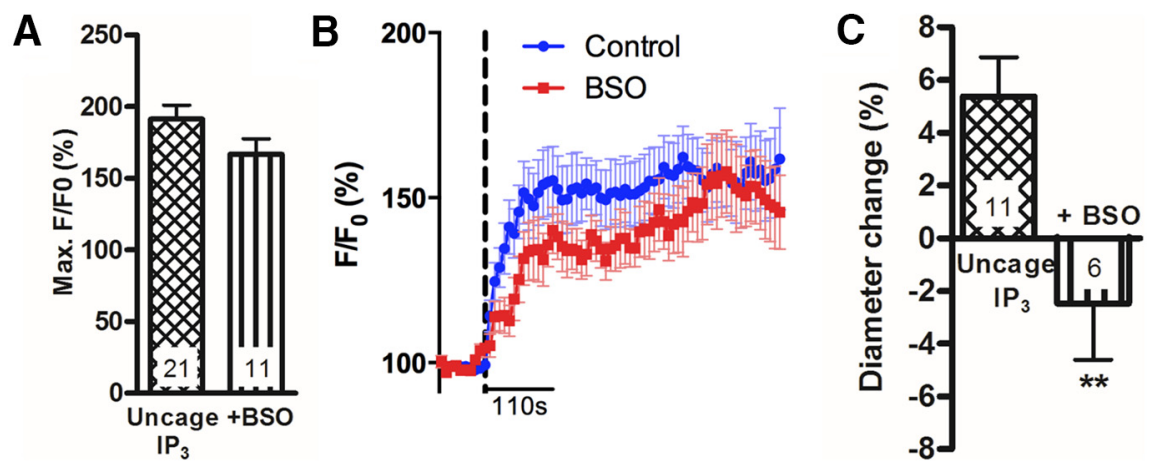

Figure 4. Astrocyte $\left[\mathrm{Ca}^{2+}\right]_{i}$ transient-evoked vasodilations are GSH dependent in vitro. $\boldsymbol{A}_{1}$ Mean $\mathrm{IP}_{3}$-evoked increases in astrocyte $\left[\mathrm{Ca}^{2+}\right]_{\mathrm{i}}$. Control, $n=21$ from 6 rats; $+\mathrm{BSO}, n=11$ from 4 rats. $B$, Mean time course of increase in astrocyte $\left[\mathrm{Ca}^{2+}\right]_{\mathrm{i}}$. Dotted line indicates time of photolysis of caged $\mathrm{IP}_{3} . n$ as described in $\boldsymbol{A}$. $\boldsymbol{C}$, Mean lumen diameter change in response to uncaging of $\mathbb{I P}_{3}$. Uncage $\mathbb{I}_{3}, n=11$ slices from 6 rats; + BSO,$n=6$ slices from 4 rats. Data are mean \pm SEM. ${ }^{* *} p<0.01$. $n$, number of experiments conducted or, for calcium measurements, number of astrocyte ROls analyzed.

using 2PLSM (Fig. $2 A-C$ ), that provided us with the ability to measure subsequent synthesis of $\mathrm{PgE}_{2}$. Applying tACPD resulted in the formation and efflux of $\mathrm{PgE}_{2}$, as measured by ELISA (Fig. $2 D)$. The first step in the conversion of $\mathrm{AA}$ to $\mathrm{PgE}_{2}$ in astrocytes is via COX-1 (Fig. 7) (Takano et al., 2006; Gordon et al., 2008; Font-Nieves et al., 2012). Neurons, in contrast, express COX-2 but not COX-1 (Nogawa et al., 1997). In support of a central role for COX-1, we found that, although the tACPD-evoked increase in astrocyte $\left[\mathrm{Ca}^{2+}\right]_{\mathrm{i}}$ was unaltered (Fig. 2C) in the presence of the COX-1 inhibitor SC560 (Smith et al., 1998; 100 nM: Blanco et al., 2008), the resulting formation and efflux of $\mathrm{PgE}_{2}$, as measured by ELISA, was abolished ( $p<0.001$; Fig. $2 D)$. Thus, astrocyte COX-1 activity is required for the subsequent $\mathrm{PgE}_{2}$ release in acute brain slices, which is triggered by astrocyte $\left[\mathrm{Ca}^{2+}\right]_{\mathrm{i}}$ signals.

Downstream of COX-1 the synthesis of $\mathrm{PgE}_{2}$ involves the enzyme mPgES-1 (Tachikawa et al., 2012), a form of prostaglandin E synthase expressed in astrocytes (Fig. 3A) (Tachikawa et al., 2012) that requires the cofactor GSH (Jakobsson et al., 1999; Murakami et al., 2000). It is known that GSH is present in high levels in astrocytes (Sun et al., 2006; Bragin et al., 2010; Robillard et al., 2011), as detected by staining of brain tissue with MCB, a GSH-sensitive dye (Fig. $3 B$ ). Therefore, we investigated whether $\mathrm{PgE}_{2}$ formation was reduced when GSH levels were depressed. We examined whether there is a reduction in astrocyte $\left[\mathrm{Ca}^{2+}\right]_{\mathrm{i}^{-}}$ evoked $\mathrm{PgE}_{2}$ release in hippocampal slices after treatment with BSO (an inhibitor of $\gamma$-glutamylcysteine synthetase) for $2.5 \mathrm{~h}$ (Sun et al., 2006), which reduced the tissue GSH concentration by $27 \%$ ( $p=0.009$; Fig. $2 E$ ). When GSH levels were decreased, although there was no change in basal $\mathrm{PgE}_{2}$ efflux (Fig. 2D) or in the amplitude of tACPD-evoked astrocyte $\left[\mathrm{Ca}^{2+}\right]_{\mathrm{i}}$ signals (Fig. $2 A-C$ ), strikingly the tACPD-evoked $\mathrm{PgE}_{2}$ efflux was reduced by $64 \%(p<0.001$; Fig. $2 D)$.

Astrocyte $\left[\mathrm{Ca}^{2+}\right]_{\mathrm{i}}$ signals evoke COX-1 and GSH-dependent vasodilations in brain slices

As COX-1 activity (Niwa et al., 2001) and $\mathrm{PgE}_{2}$ release (Wagerle and Mishra, 1988; Wagerle and Degiulio, 1994) have been shown to lead to increased CBF in response to hypercapnia, we examined whether COX-1-dependent $\mathrm{PgE}_{2}$ release evoked by astrocyte $\left[\mathrm{Ca}^{2+}\right]_{\mathrm{i}}$ signals triggered by either tACPD application or $\mathrm{IP}_{3}$ uncaging resulted in vasodilations.

Bath perfusion of tACPD induced arteriolar dilation in acute brain slices (Fig. $2 A, F, G)$, which was abolished in the presence of SC560 ( $p<0.01$; Fig. $2 G)$, whereas the amplitude of evoked astrocyte $\left[\mathrm{Ca}^{2+}\right]_{\mathrm{i}}$ signals was unchanged $(p>0.05$; Fig. $2 C)$. Thus, combined with the results discussed above, these data confirm that astrocyte COX-1 activity and subsequent $\mathrm{PgE}_{2}$ release are required for vasodilations in acute brain slices that are triggered by astrocyte $\left[\mathrm{Ca}^{2+}\right]_{\mathrm{i}}$ signals.

As previously discussed, downstream of COX-1, the synthesis of $\mathrm{PgE}_{2}$ involves the astrocyte-expressed, GSH-dependent, enzyme mPgES-1 (Tachikawa et al., 2012). Therefore, a role for astrocytes in the regulation of arteriole diameter would be supported if $\left[\mathrm{Ca}^{2+}\right]_{\mathrm{i}}$-evoked vasodilations were attenuated when GSH levels were depressed. We examined whether there is a reduction in subsequent vasodilations in hippocampal slices after treatment with BSO. When GSH levels were decreased, tACPDevoked astrocyte $\left[\mathrm{Ca}^{2+}\right]_{\mathrm{i}}$ signals were unaltered (Fig. $2 A-C$ ). However, the vasodilations triggered by these $\left[\mathrm{Ca}^{2+}\right]_{\mathrm{i}}$ signals were abolished (Fig. 2A,F,G; $p<0.01$ ). Vasoconstrictions evoked by NE $(100 \mu \mathrm{M})$ or the $\alpha_{2}$ agonist clonidine $(10 \mu \mathrm{M})$, which act directly on arteriole smooth muscle cells (Busija and Leffler, 1987), were unchanged in the presence of BSO (Fig. $2 A, G, H)$, indicating that arterioles were not damaged by the BSO treatment. Furthermore, BSO treatment did not alter the vasodilation evoked by either $1 \mu \mathrm{M} \operatorname{PgE}_{2}$ (Fig. $2 \mathrm{H}$ ) or high $\left[\mathrm{K}^{+}\right](10 \mathrm{~mm}$ ), which causes vasodilation by hyperpolarizing arteriole smooth muscle cells (Filosa et al., 2006) $\left(\mathrm{K}^{+}: 8.6 \pm 2.3 \%, n=5\right.$ slices from 5 rats; $\mathrm{BSO}+\mathrm{K}^{+}$: $6.5 \pm 0.8 \%, n=6$ slices from 3 rats, $p=0.37$ ).

Astrocyte $\left[\mathrm{Ca}^{2+}\right]_{\mathrm{i}}$ increases can be triggered by two-photon uncaging of $\mathrm{IP}_{3}$ within the cell body of an astrocyte. Using this 

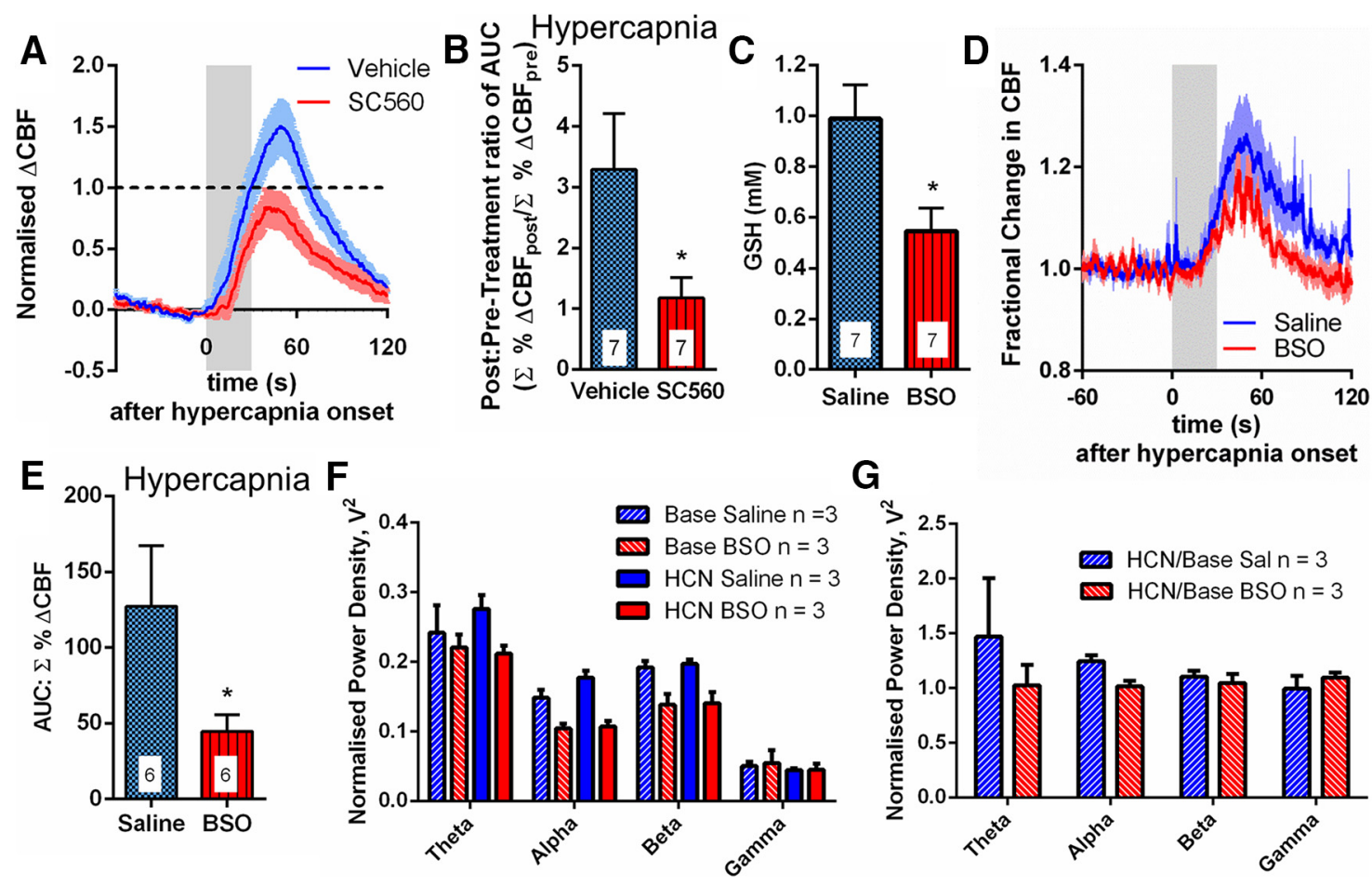

Figure 5. $\mathrm{CO}_{2}$ evoked CBF responses in vivo are GSH dependent. $A$, Mean traces of local CBF response to hypercapnia, measured by laser speckle contrast imaging, in vehicle (DMSO)- (blue) and SC560-(red) injected animals. $n=7$ rats for each group. Colored box represents time of $\mathrm{CO}_{2}$ application. Data shown as fractional change with baseline of 0 (baseline taken during $60 \mathrm{~s}$ prechallenge) and a pretreatment peak of 1 (black dotted line on graph). $\boldsymbol{B}$, Mean AUC of CBF response to hypercapnia in the presence of vehicle (DMSO) or SC560 (normalized to pretreatment maxima for each animal). $n=7$ rats for each group. C, Tissue GSH levels $24 \mathrm{~h}$ after injection of BSO or saline into the barrel cortex ( $n=7$ rats). D, Mean trace of local CBF response to hypercapnia, measured by laser Doppler flowmetry, in saline- (blue) and BSO-(red) injected rats. $n=6$ rats in each group. $\boldsymbol{E}$, Mean values of AUC of (BF response to hypercapnia. $n=6$ rats in each group. $\boldsymbol{F}, \boldsymbol{G}$, Neural activity. Power in frequency bands. $\boldsymbol{F}$, During baseline (Base) and in response to hypercapnia (HCN) for saline- (blue) and BSO- (red) treated animals. $n=3$ rats. G, Hypercapnia (HCN)/baseline (Base). Treatment with BSO does not change the effect of hypercapnia on neural activity. $n=3$ rats. Data are mean \pm SEM. ${ }^{*} p<0.05$.

technique, we directly examined the effect of decreasing GSH levels on astrocyte $\left[\mathrm{Ca}^{2+}\right]_{\mathrm{i}}$-evoked arteriole dilations. Astrocytes in hippocampal slices from juvenile rats were bulk-loaded with the caged $\mathrm{IP}_{3}$ compound, NV-IP $/ \mathrm{AM}$. Two-photon photolysis was used to uncage $\mathrm{IP}_{3}$ within an astrocyte soma specifically, generating a $\left[\mathrm{Ca}^{2+}\right]_{\mathrm{i}}$ increase within the soma, processes, and endfeet. This local increase in $\left[\mathrm{Ca}^{2+}\right]_{\mathrm{i}}$ could evoke an increase in $\left[\mathrm{Ca}^{2+}\right]_{\mathrm{i}}$ in nearby astrocytes (Fig. $4 A, B$ represents local and propagated responses) and elicited vasodilation of the neighboring arteriole (Fig. 4C). Although astrocyte $\left[\mathrm{Ca}^{2+}\right]_{\mathrm{i}}$ signals were unaltered following BSO treatment to reduce GSH levels ( $p=0.1$; Fig. $4 A, B$ ), dilations were not observed and vasoconstrictions were now evoked ( $p=0.008$; Fig. $4 C$ ). Thus, when GSH levels are reduced, astrocyte $\left[\mathrm{Ca}^{2+}\right]_{\mathrm{i}}$ signals can no longer evoke vasodilations normally triggered by the release of $\mathrm{PgE}_{2}$.

\section{In vivo hypercapnia-evoked $\mathrm{CBF}$ responses are \\ GSH dependent}

Having determined in acute brain slices the vasodilatory molecules underlying astrocyte $\left[\mathrm{Ca}^{2+}\right]_{\mathrm{i}}$-evoked vasodilations, we examined whether these same enzymes and molecules were involved in the CBF response, which occurs downstream of $\mathrm{CO}_{2}$-evoked astrocyte $\left[\mathrm{Ca}^{2+}\right]_{\mathrm{i}}$ responses in vivo. Hypercapnia in vivo evoked a CBF increase in the barrel cortex of adult rat (Fig. $5 A, B, D, E$ ), whereas neural activity was unchanged (Fig. $5 F$ ). The calculated area under the curve (AUC) of the CBF response was significantly attenuated by SC560 ( $p=$ 0.032; Fig. $5 A, B)$, confirming that COX-1 plays a critical role in hypercapnia-evoked CBF increases in vivo (Niwa et al., 2001).
We examined the impact of decreased tissue GSH levels on $\mathrm{CO}_{2}$ evoked CBF increases in vivo. To lower GSH levels in vivo, $\mathrm{BSO}$ was injected into rat barrel cortex. After $24 \mathrm{~h}$, tissue GSH levels in the ipsilateral cortex were reduced by $45 \%$ (Fig. $5 C ; p=0.018$ ). Treatment with $\mathrm{BSO}$ reduced the hypercapnia-evoked CBF response (Fig. $5 D, E$; AUC reduced by $65 \%, p=0.048)$. Neural activity was no different in BSO-treated rats compared with saline-treated rats (Fig. $5 G$ ). Combining all the data described so far suggests that hypercapnia-evoked, astrocyte $\left[\mathrm{Ca}^{2+}\right]_{\mathrm{i}}$-related, $\mathrm{CBF}$ increases require $\mathrm{PgE}_{2}$ release and, thus, are compromised when brain GSH levels are reduced.

This finding was specific to hypercapnia-evoked CBF increases. We examined the impact of decreased tissue GSH levels in vivo on functional hyperemia in the somatosensory cortex. Whisker pad stimulation $(10 \mathrm{~Hz})$ evoked a blood flow increase in the barrel cortex (Fig. 6A). In agreement with previous findings (Niwa et al., 2000), inhibiting COX-1 with SC560 had no effect on either the CBF response to whisker pad stimulation (Fig. $6 A, B ; p=0.10$ ) or evoked neural activity (LFP) (Fig. $6 C ; p=0.91$ ). Furthermore, the AUC of the stimulation-evoked $\mathrm{CBF}$ response was not significantly different in BSO-treated animals (Fig. $6 D ; p=0.14$ ) compared with salinetreated animals, demonstrating that the CBF response is not GSHsensitive. The magnitude of the neural response to whisker pad stimulation was unaffected by BSO (Fig. $6 E ; p=0.68$ ). These results indicate that, under these experimental conditions, COX-1 and GSH play little, if any, role in the CBF response to somatosensory stimulation. These findings confirm that several different pathways exist that account for CBF regulation under differing conditions and in response to different stimuli. 
A

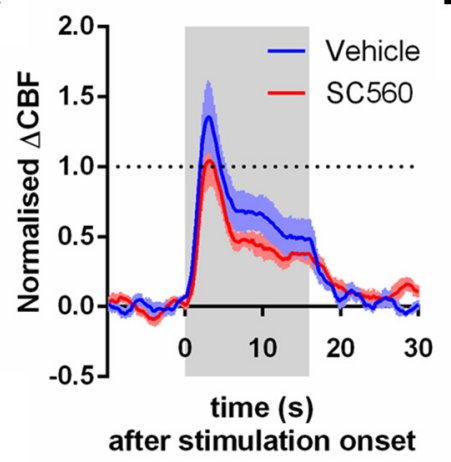

E

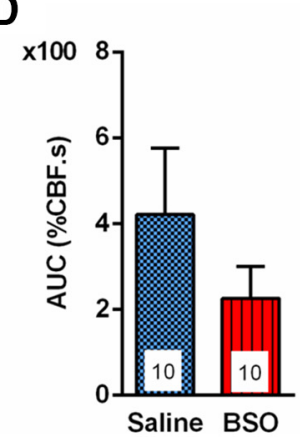

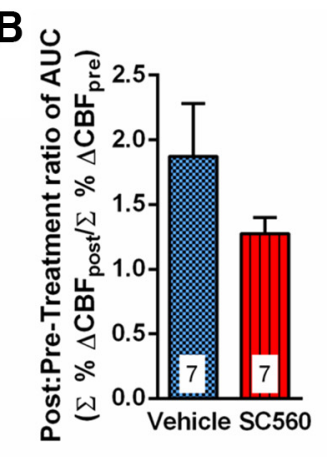
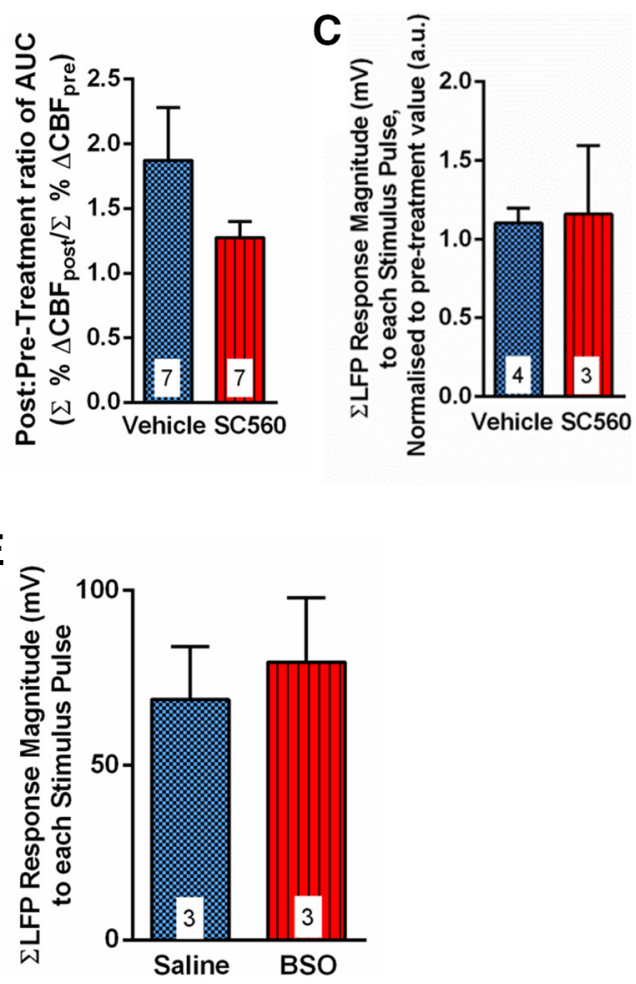

Figure 6. CBF responses to whisker pad stimulation in vivo are independent of GSH. $A$, Mean time course of local CBF response to whisker pad stimulation, measured by laser speckle contrast imaging, in vehicle (DMSO)- (blue) and SC560(red) injected rats. Colored box represents time of stimulation. Dotted black line indicates pretreatment peak of 1. $\boldsymbol{B}$, Mean AUC of the CBF response to whisker pad stimulation. $n=7$ rats for each group. $C$, Mean neural response (LFP) magnitude to whisker pad stimulus (summed over total $16 \mathrm{~s}$ length of stimulus). Responses are normalized to the first pulse response for each rat. $n=4$ DMSO-treated rats; $n=3$ SC560-treated rats. D, Mean AUC of the whisker pad stimulation-evoked (BF response in saline- (blue) and BSO- (red) injected rats. $n=10$ rats for each group. $\boldsymbol{E}$, Mean neural response (LFP) magnitude to whisker pad stimulation (summed over total $16 \mathrm{~s}$ length of stimulus). Responses are normalized to the first pulse response for each rat. $n=3$ rats in each group. Data are mean \pm SEM.

\section{Discussion}

We demonstrate a novel mechanism of CBF regulation involving astrocytes, which is GSH dependent. Previously, Niwa et al. (2001) demonstrated that hypercapnia-evoked CBF increases are principally COX-1 dependent. In this study, we examined the mechanism of such $\mathrm{CBF}$ regulation, both upstream and downstream of hypercapnia-evoked increases in COX-1 activity (Fig. 7). We demonstrate in vivo that, upstream of evoked COX-1 activity, $\mathrm{CO}_{2}$ increases $\left[\mathrm{Ca}^{2+}\right]_{\mathrm{i}}$ in astrocytes. These data demonstrate a new signal (hypercapnia) that activates astrocyte calcium and specifically identify the involvement of astrocytes in the regulation of $\mathrm{CBF}$ in response to changes in arterial $\mathrm{CO}_{2}$.

In vitro, using brain slices from juvenile animals in which it is possible to examine calcium signals by bulk loading a calcium indicator dye, we confirm that increased astrocyte $\left[\mathrm{Ca}^{2+}\right]_{\mathrm{i}}$ results in the subsequent release of $\mathrm{PgE}_{2}$ and vasodilation which are COX-1 activity-dependent (Fig. 7). Our assumption that the evoked response in juvenile rat slices is the same as in adult rat with respect to COX-1 dependence is supported by the fact that the same COX-1 dependence has been shown in adult mice (Takano et al., 2006). We demonstrate that these findings hold in vivo, confirming previous findings in adult mice (Niwa et al., 2001). Astrocytic endfeet, which are apposed to cerebral vascular smooth muscle, express all the machinery necessary for $\mathrm{PgE}_{2}$ synthesis (COX-1) (Takano et al., 2006; Gordon et al., 2008), mPgES-1 (Fig. 3A) (Tachikawa et al., 2012), and GSH: (Fig. 3B) (Sun et al., 2006;

Bragin et al., 2010; Robillard et al., 2011), providing further evidence for the involvement of astrocytes in the regulation of $\mathrm{CBF}$ responses to hypercapnia. mPgES, an enzyme selectively expressed in astrocytes compared with neurons (Tachikawa et al., 2012), is the enzyme responsible for producing $\mathrm{PgE}_{2}$ downstream of COX-1 activity. Intriguingly, the formation of $\mathrm{PgE}_{2}$ is regulated by the availability of GSH in astrocytes, as $\mathrm{PgES}$ requires GSH as a cofactor (Jakobsson et al., 1999; Murakami et al., 2000). In vitro, we demonstrate that astrocyte $\left[\mathrm{Ca}^{2+}\right]_{\mathrm{i}}$-evoked vasodilations are attenuated when GSH levels are depleted, whereas in vivo, we demonstrate that $\mathrm{CO}_{2}$-evoked $\mathrm{CBF}$ increases occur via a GSH-dependent mechanism. As astrocytes contain high levels of GSH (Fig. 3B) (Sun et al., 2006; Bragin et al., 2010; Robillard et al., 2011), the dependence of the $\mathrm{CO}_{2}$-evoked $\mathrm{CBF}$ response on GSH is further evidence of astrocytic involvement. Together, our findings suggest a novel mechanism of astrocyteevoked CBF regulation, which is GSH dependent. We propose that increased $\mathrm{CO}_{2}$ levels evoke $\left[\mathrm{Ca}^{2+}\right]_{\mathrm{i}}$ responses in astrocytes, subsequently activating a signaling pathway, involving COX-1 and the GSH-dependent PgES, which results in the release of the vasodilator $\mathrm{PgE}_{2}$. Thus, an increase in $\mathrm{CO}_{2}$ results in an astrocyte-driven, GSH-dependent vasodilation (Fig. 7).

This GSH-dependent mechanism of CBF regulation exists alongside other COX-1 and GSH-insensitive mechanisms. For example, we found no effect of blocking COX-1 activity or of lowering GSH levels on CBF responses following $10 \mathrm{~Hz}$ whisker pad stimulation. Although it is possible that an astrocyte calcium response (and, thus, a GSH-sensitive mechanism of CBF regulation) may be evoked by an intense sensory stimulus (Schulz et al., 2012; Sekiguchi et al., 2016), our results are in agreement with previous work suggesting that COX-1 is involved in CBF responses to hypercapnia (Niwa et al., 2001) but not sensory stimulation (Niwa et al., 2000). Although we saw no evidence that this pathway was important for functional (neuronal activityevoked) increases in CBF under our experimental conditions, astrocytes appear to be an important intermediary for physiological (hypercapnia-evoked) increases in CBF. Our findings suggest that $\mathrm{CBF}$ regulation may involve astrocytes, and their $\left[\mathrm{Ca}^{2+}\right]_{\mathrm{i}}$ signals, under certain conditions and not under others.

Previous studies have provided evidence for several mechanisms linking astrocyte $\left[\mathrm{Ca}^{2+}\right]_{i}$, increases and changes in $\mathrm{CO}_{2}$ concentration. For example, within the respiratory center, increased astrocyte $\left[\mathrm{Ca}^{2+}\right]_{\mathrm{i}}$, and astrocytic release of ATP can be triggered by $\mathrm{CO}_{2}$-evoked decreases in $\mathrm{pH}$ (Gourine et al., 2010). This $\left[\mathrm{Ca}^{2+}\right]_{\mathrm{i}}$, increase may be the result of increased $\mathrm{Na}^{+} / \mathrm{HCO}_{3}^{-}$ cotransport and reversal of $\mathrm{Na}^{+} / \mathrm{Ca}^{2+}$ transport (Turovsky et al., 2016). It is unknown whether this mechanism also occurs within the cortex. Alternatively, increased $\mathrm{CO}_{2}$ can evoke hemichannelmediated release of ATP (Huckstepp et al., 2010), which may act 


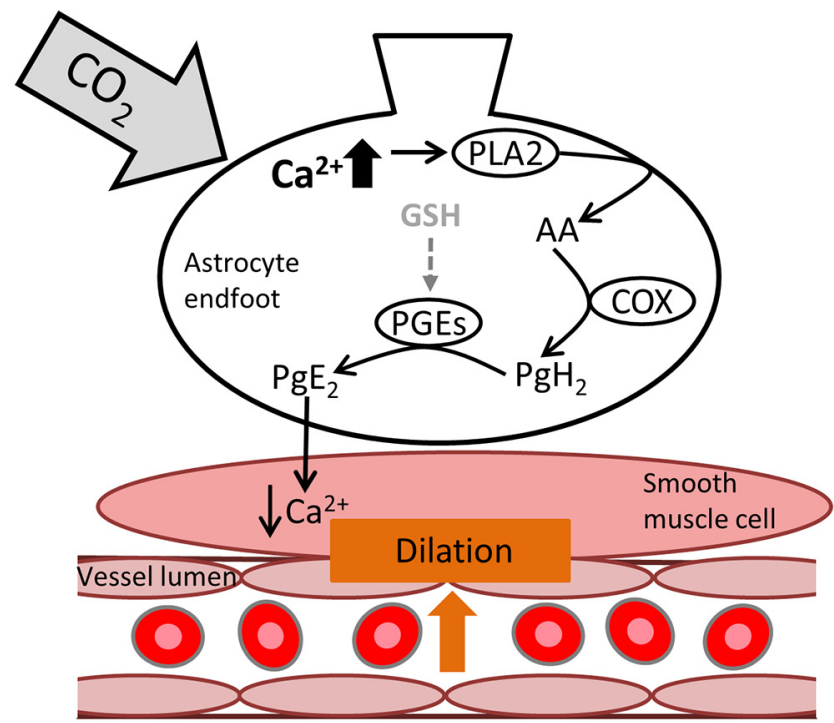

Figure 7. Increases in astrocytic $\left[\mathrm{Ca}^{2+}\right]_{\mathrm{i}}$ may lead to GSH-dependent, $\mathrm{PgE}_{2}$-mediated vasodilation. Schematic diagram depicting how $\mathrm{CO}_{2}$-evoked increases in astrocytic $\left[\mathrm{Ca}^{2+}\right]_{i}$ may lead to $\mathrm{PgE}_{2}$-mediated vasodilation. As a result of elevated $\left[\mathrm{Ca}^{2+}\right]_{\mathrm{i}}, \mathrm{PLA}_{2}$ is activated. PLA $A_{2}$ generates AA from the plasma membrane. AA can be processed locally by COX enzymes to produce AA derivatives, such as prostaglandin $\mathrm{H}_{2}\left(\mathrm{PgH}_{2}\right)$. $\mathrm{PgE}_{2}$ is produced from $\mathrm{PgH}_{2}$ by the enzyme PGEs, which requires GSH as a cofactor (Jakobsson et al., 1999; Murakami et al., 2000; Tanioka et al., 2000). $\mathrm{PgE}_{2}$ is released from astrocyte endfeet, which are apposed to the smooth muscle layer surrounding arterioles, resulting in activation of $\mathrm{K}^{+}$channels, a decrease in $\mathrm{Ca}^{2+}$ entry into the smooth muscle cell and vasodilation.

on astrocytic purinergic receptors to elicit an increase in $\left[\mathrm{Ca}^{2+}\right]_{\mathrm{i}}$ (Pelligrino et al., 2011). Depending on the mechanism linking increases in $\mathrm{CO}_{2}$ to astrocyte $\left[\mathrm{Ca}^{2+}\right]_{\mathrm{i}}$ responses, therefore, astrocytes could act as either a $\mathrm{pH}$ or $\mathrm{CO}_{2}$ sensor. Although it is beyond the scope of this paper to determine the link between an increase in $\mathrm{CO}_{2}$ and the increase in astrocyte $\left[\mathrm{Ca}^{2+}\right]_{\mathrm{i}}$, we have demonstrated that the depletion of GSH levels leads to a reduction in the ability of astrocytes to release $\mathrm{PgE}_{2}$ following such a rise in $\left[\mathrm{Ca}^{2+}\right]_{\mathrm{i}}$, and so reduces their ability to evoke vasodilation in response to hypercapnia. This occurs because astrocytes express GSH-dependent mPgES- 1 .

Our finding that $\mathrm{CBF}$ responses to increased $\mathrm{CO}_{2}$ are $\mathrm{GSH}-$ sensitive suggests that global CBF regulation, which is sensitive to the partial pressure of arterial $\mathrm{CO}_{2}$ (Ainslie and Duffin, 2009), will be affected in conditions where GSH levels are depleted. Alterations in the redox status of brain tissue that are ultimately linked to cellular GSH levels have been observed in numerous neurological and psychiatric disorders (Slivka and Cohen, 1993; Tohgi et al., 1995, 1999; Ansari and Scheff, 2010; Zhang et al., 2012; Kulak et al., 2013). Therefore, the impact of changes in GSH levels on the sensitivity of astrocyte regulation of vasodilation could contribute to several CNS pathologies. Thus, it is critical to understand the signaling pathways underlying changes in CBF, both in health and disease.

It has previously been shown that, in addition to astrocytic production of $\mathrm{PgE}_{2}$ via $\mathrm{COX}-1 / \mathrm{mPgES}$ activity, neurons (which express COX-2 but not COX-1) (Nogawa et al., 1997; Lecrux et al., 2011), are capable of producing COX-2-derived $\mathrm{PgE}_{2}$ (which contributes to neurovascular coupling) (Lecrux et al., 2011; Lacroix et al., 2015). In this study, we used a pharmacological approach to increase astrocyte $\left[\mathrm{Ca}^{2+}\right]_{\mathrm{i}}$ and to inhibit either the de novo synthesis of glutathione or the activity of COX-1, specifically, to demonstrate that, down- stream of an increase in astrocyte $\left[\mathrm{Ca}^{2+}\right]_{\mathrm{i}}, \mathrm{COX}-1$ activity and glutathione are required for vasodilation to occur. However, as this pharmacological approach lacks cellular specificity, a contribution of neuronally produced $\mathrm{PgE}_{2}$ to the hypercapniaevoked CBF response cannot be completely excluded. Nevertheless, our conclusion that astrocyte COX-1-derived $\mathrm{PgE}_{2}$, rather than neuronal COX-2-derived $\mathrm{PgE}_{2}$, is involved in the CBF response to hypercapnia is in agreement with previous findings (Niwa et al., 2001). Future studies could use an astrocyte-specific genetic strategy (such as cell-specific knockout) (Casper et al., 2007) to confirm that hypercapnia-evoked vasodilations, occurring downstream of astrocyte $\left[\mathrm{Ca}^{2+}\right]_{\mathrm{i}}$ responses, are dependent on astrocyte glutathione levels and COX-1 activity.

In conclusion, we demonstrate a novel mechanism by which astrocytes detect hypercapnia and, via $\left[\mathrm{Ca}^{2+}\right]_{\mathrm{i}}$ signals, increase $\mathrm{CBF}$ in response to $\mathrm{CO}_{2}$. Astrocytes are therefore poised to detect the metabolic activity of neurons and to modify vascular tone appropriately to deliver glucose and $\mathrm{O}_{2}$. This important pathway may be impaired in conditions in which oxidative stress reduces GSH levels in astrocytes, leading to impaired $\mathrm{CBF}$ responses and altered vascular readouts of neural activity.

\section{References}

Ainslie PN, Duffin J (2009) Integration of cerebrovascular $\mathrm{CO}_{2}$ reactivity and chemoreflex control of breathing: mechanisms of regulation, measurement, and interpretation. Am J Physiol Regul Integr Comp Physiol 296:R1473-R1495. CrossRef Medline

Ansari MA, Scheff SW (2010) Oxidative stress in the progression of Alzheimer disease in the frontal cortex. J Neuropathol Exp Neurol 69:155-167. CrossRef Medline

Attwell D, Buchan AM, Charpak S, Lauritzen M, Macvicar BA, Newman EA (2010) Glial and neuronal control of brain blood flow. Nature 468:232243. CrossRef Medline

Blanco VM, Stern JE, Filosa JA (2008) Tone-dependent vascular responses to astrocyte-derived signals. Am J Physiol 294:H2855-H2863. CrossRef Medline

Bonder DE, McCarthy KD (2014) Astrocytic Gq-GPCR-linked IP3Rdependent $\mathrm{Ca}^{2+}$ signaling does not mediate neurovascular coupling in mouse visual cortex in vivo. J Neurosci 34:13139-13150. CrossRef Medline

Bragin DE, Zhou B, Ramamoorthy P, Müller WS, Connor JA, Shi H (2010) Differential changes of glutathione levels in astrocytes and neurons in ischemic brains by two-photon imaging. J Cereb Blood Flow Metab 30: 734-738. CrossRef Medline

Busija DW, Leffler CW (1987) Exogenous norepinephrine constricts cerebral arterioles via alpha 2-adrenoceptors in newborn pigs. J Cereb Blood Flow Metab 7:184-188. CrossRef Medline

Cahoy JD, Emery B, Kaushal A, Foo LC, Zamanian JL, Christopherson KS, Xing Y, Lubischer JL, Krieg PA, Krupenko SA, Thompson WJ, Barres BA (2008) A transcriptome database for astrocytes, neurons, and oligodendrocytes: a new resource for understanding brain development and function. J Neurosci 28:264-278. CrossRef Medline

Casper KB, Jones K, McCarthy KD (2007) Characterization of astrocytespecific conditional knockouts. Genesis 45:292-299. CrossRef Medline

Duffy S, MacVicar BA (1995) Adrenergic calcium signaling in astrocyte networks within the hippocampal slice. J Neurosci 15:5535-5550. Medline

Filosa JA, Bonev AD, Straub SV, Meredith AL, Wilkerson MK, Aldrich RW, Nelson MT (2006) Local potassium signaling couples neuronal activity to vasodilation in the brain. Nat Neurosci 9:1397-1403. CrossRef Medline

Font-Nieves M, Sans-Fons MG, Gorina R, Bonfill-Teixidor E, Salas-Pérdomo A, Márquez-Kisinousky L, Santalucia T, Planas AM (2012) Induction of COX-2 enzyme and down-regulation of COX-1 expression by lipopolysaccharide (LPS) control prostaglandin E2 production in astrocytes. J Biol Chem 287:6454-6468. CrossRef Medline

Gordon GR, Choi HB, Rungta RL, Ellis-Davies GC, MacVicar BA (2008) Brain metabolism dictates the polarity of astrocyte control over arterioles. Nature 456:745-749. CrossRef Medline 
Gourine AV, Kasymov V, Marina N, Tang F, Figueiredo MF, Lane S, Teschemacher AG, Spyer KM, Deisseroth K, Kasparov S (2010) Astrocytes control breathing through pH-dependent release of ATP. Science 329: 571-575. CrossRef Medline

Hauge A, Thoresen M, Walløe L (1980) Changes in cerebral blood flow during hyperventilation and $\mathrm{CO}_{2}$-breathing measured transcutaneously in humans by a bidirectional, pulsed, ultrasound Doppler blood velocitymeter. Acta Physiol Scand 110:167-173. CrossRef Medline

He L, Linden DJ, Sapirstein A (2012) Astrocyte inositol triphosphate receptor type 2 and cytosolic phospholipase A2 alpha regulate arteriole responses in mouse neocortical brain slices. PLoS One 7:e42194. CrossRef Medline

Huckstepp RT, id Bihi R, Eason R, Spyer KM, Dicke N, Willecke K, Marina N, Gourine AV, Dale N (2010) Connexin hemichannel-mediated $\mathrm{CO}_{2}-$ dependent release of ATP in the medulla oblongata contributes to central respiratory chemosensitivity. J Physiol 588:3901-3920. CrossRef Medline

Jakobsson PJ, Thorén S, Morgenstern R, Samuelsson B (1999) Identification of human prostaglandin $\mathrm{E}$ synthase: a microsomal, glutathionedependent, inducible enzyme, constituting a potential novel drug target. Proc Natl Acad Sci U S A 96:7220-7225. CrossRef Medline

Kulak A, Steullet P, Cabungcal JH, Werge T, Ingason A, Cuenod M, Do KQ (2013) Redox dysregulation in the pathophysiology of schizophrenia and bipolar disorder: insights from animal models. Antioxid Redox Signal 18:1428-1443. CrossRef Medline

Lacroix A, Toussay X, Anenberg E, Lecrux C, Ferreirós N, Karagiannis A, Plaisier F, Chausson P, Jarlier F, Burgess SA, Hillman EM, Tegeder I, Murphy TH, Hamel E, Cauli B (2015) COX-2-derived prostaglandin E2 produced by pyramidal neurons contributes to neurovascular coupling in the rodent cerebral cortex. J Neurosci 35:11791-11810. CrossRef Medline

Lathia JD, Okun E, Tang SC, Griffioen K, Cheng A, Mughal MR, Laryea G, Selvaraj PK, ffrench-Constant C, Magnus T, Arumugam TV, Mattson MP (2008) Toll-like receptor 3 is a negative regulator of embryonic neural progenitor cell proliferation. J Neurosci 28:13978-13984. CrossRef Medline

Lecrux C, Toussay X, Kocharyan A, Fernandes P, Neupane S, Lévesque M, Plaisier F, Shmuel A, Cauli B, Hamel E (2011) Pyramidal neurons are "neurogenic hubs" in the neurovascular coupling response to whisker stimulation. J Neurosci 31:9836-9847. CrossRef Medline

Lind BL, Brazhe AR, Jessen SB, Tan FC, Lauritzen MJ (2013) Rapid stimulus-evoked astrocyte $\mathrm{Ca}^{2+}$ elevations and hemodynamic responses in mouse somatosensory cortex in vivo. Proc Natl Acad Sci U S A 110: E4678-E4687. CrossRef Medline

Mulligan SJ, MacVicar BA (2004) Calcium transients in astrocyte endfeet cause cerebrovascular constrictions. Nature 431:195-199. CrossRef Medline

Murakami M, Naraba H, Tanioka T, Semmyo N, Nakatani Y, Kojima F, Ikeda T, Fueki M, Ueno A, Oh S, Kudo I (2000) Regulation of prostaglandin E2 biosynthesis by inducible membrane-associated prostaglandin E2 synthase that acts in concert with cyclooxygenase-2. J Biol Chem 275:3278332792. CrossRef Medline

Nimmerjahn A, Kirchhoff F, Kerr JN, Helmchen F (2004) Sulforhodamine 101 as a specific marker of astroglia in the neocortex in vivo. Nat Methods 1:31-37. CrossRef Medline

Niwa K, Araki E, Morham SG, Ross ME, Iadecola C (2000) Cyclooxygenase-2 contributes to functional hyperemia in whisker-barrel cortex. J Neurosci 20:763-770. Medline

Niwa K, Haensel C, Ross ME, Iadecola C (2001) Cyclooxygenase-1 participates in selected vasodilator responses of the cerebral circulation. Circ Res 88:600-608. CrossRef Medline

Nizar K, Uhlirova H, Tian P, Saisan PA, Cheng Q, Reznichenko L, Weldy KL, Steed TC, Sridhar VB, MacDonald CL, Cui J, Gratiy SL, Sakadzić S, Boas DA, Beka TI, Einevoll GT, Chen J, Masliah E, Dale AM, Silva GA, et al. (2013) In vivo stimulus-induced vasodilation occurs without IP3 receptor activation and may precede astrocytic calcium increase. J Neurosci 33:8411-8422. CrossRef Medline

Nogawa S, Zhang F, Ross ME, Iadecola C (1997) Cyclo-oxygenase-2 gene expression in neurons contributes to ischemic brain damage. J Neurosci 17:2746-2755. Medline

Olajide OA, Velagapudi R, Okorji UP, Sarker SD, Fiebich BL (2014) Picralima nitida seeds suppress PGE2 production by interfering with multiple signalling pathways in IL-1beta-stimulated SK-N-SH neuronal cells. J Ethnopharmacol 152:377-383. CrossRef Medline
Otsu Y, Couchman K, Lyons DG, Collot M, Agarwal A, Mallet JM, Pfrieger FW, Bergles DE, Charpak S (2015) Calcium dynamics in astrocyte processes during neurovascular coupling. Nat Neurosci 18:210-218. CrossRef Medline

Pelligrino DA, Vetri F, Xu HL (2011) Purinergic mechanisms in gliovascular coupling. Semin Cell Dev Biol 22:229-236. CrossRef Medline

Petzold GC, Albeanu DF, Sato TF, Murthy VN (2008) Coupling of neural activity to blood flow in olfactory glomeruli is mediated by astrocytic pathways. Neuron 58:897-910. CrossRef Medline

Pileblad E, Magnusson T (1989) Intracerebroventricular administration of L-buthionine sulfoximine: a method for depleting brain glutathione. J Neurochem 53:1878-1882. CrossRef Medline

Robillard JM, Gordon GR, Choi HB, Christie BR, MacVicar BA (2011) Glutathione restores the mechanism of synaptic plasticity in aged mice to that of the adult. PLoS One 6:e20676. CrossRef Medline

Rosenegger DG, Tran CH, Wamsteeker Cusulin JI, Gordon GR (2015) Tonic local brain blood flow control by astrocytes independent of phasic neurovascular coupling. J Neurosci 35:13463-13474. CrossRef Medline

Schulz K, Sydekum E, Krueppel R, Engelbrecht CJ, Schlegel F, Schröter A, Rudin M, Helmchen F (2012) Simultaneous BOLD fMRI and fiberoptic calcium recording in rat neocortex. Nat Methods 9:597-602. CrossRef Medline

Sekiguchi KJ, Shekhtmeyster P, Merten K, Arena A, Cook D, Hoffman E, Ngo A, Nimmerjahn A (2016) Imaging large-scale cellular activity in spinal cord of freely behaving mice. Nat Commun 7:11450. CrossRef Medline

Slivka A, Cohen G (1993) Brain ischemia markedly elevates levels of the neurotoxic amino acid, cysteine. Brain Res 608:33-37. CrossRef Medline

Smith CJ, Zhang Y, Koboldt CM, Muhammad J, Zweifel BS, Shaffer A, Talley JJ, Masferrer JL, Seibert K, Isakson PC (1998) Pharmacological analysis of cyclooxygenase-1 in inflammation. Proc Natl Acad Sci U S A 95: 13313-13318. CrossRef Medline

Sun W, McConnell E, Pare JF, Xu Q, Chen M, Peng W, Lovatt D, Han X, Smith Y, Nedergaard M (2013) Glutamate-dependent neuroglial calcium signaling differs between young and adult brain. Science 339:197200. CrossRef Medline

Sun X, Shih AY, Johannssen HC, Erb H, Li P, Murphy TH (2006) Twophoton imaging of glutathione levels in intact brain indicates enhanced redox buffering in developing neurons and cells at the cerebrospinal fluid and blood-brain interface. J Biol Chem 281:17420-17431. CrossRef Medline

Tachikawa M, Ozeki G, Higuchi T, Akanuma S, Tsuji K, Hosoya K (2012) Role of the blood-cerebrospinal fluid barrier transporter as a cerebral clearance system for prostaglandin E(2) produced in the brain. J Neurochem 123:750-760. CrossRef Medline

Takano T, Tian GF, Peng W, Lou N, Libionka W, Han X, Nedergaard M (2006) Astrocyte-mediated control of cerebral blood flow. Nat Neurosci 9:260-267. CrossRef Medline

Takata N, Nagai T, Ozawa K, Oe Y, Mikoshiba K, Hirase H (2013) Cerebral blood flow modulation by basal forebrain or whisker stimulation can occur independently of large cytosolic $\mathrm{Ca}^{2+}$ signaling in astrocytes. PLoS One 8:e66525. CrossRef Medline

Tanioka T, Nakatani Y, Semmyo N, Murakami M, Kudo I (2000) Molecular identification of cytosolic prostaglandin E2 synthase that is functionally coupled with cyclooxygenase- 1 in immediate prostaglandin E2 biosynthesis. J Biol Chem 275:32775-32782. CrossRef Medline

Teng XW, Abu-Mellal AK, Davies NM (2003) Formulation dependent pharmacokinetics, bioavailability and renal toxicity of a selective cyclooxygenase-1 inhibitor SC-560 in the rat. J Pharm Pharmacol Sci 6:205-210. Medline

Tohgi H, Abe T, Saheki M, Hamato F, Sasaki K, Takahashi S (1995) Reduced and oxidized forms of glutathione and alpha-tocopherol in the cerebrospinal fluid of parkinsonian patients: comparison between before and after L-dopa treatment. Neurosci Lett 184:21-24. CrossRef Medline

Tohgi H, Abe T, Yamazaki K, Murata T, Ishizaki E, Isobe C (1999) Increase in oxidized NO products and reduction in oxidized glutathione in cerebrospinal fluid from patients with sporadic form of amyotrophic lateral sclerosis. Neurosci Lett 260:204-206. CrossRef Medline 
Turovsky E, Theparambil SM, Kasymov V, Deitmer JW, Del Arroyo AG, Ackland GL, Corneveaux JJ, Allen AN, Huentelman MJ, Kasparov S, Marina N, Gourine AV (2016) Mechanisms of $\mathrm{CO}_{2} / \mathrm{H}^{+}$sensitivity of astrocytes. J Neurosci 36:10750-10758. CrossRef Medline

Tuure L, Hämäläinen M, Moilanen T, Moilanen E (2015) Aurothiomalate inhibits the expression of mPGES-1 in primary human chondrocytes. Scand J Rheumatol 44:74-79. CrossRef Medline

Wagerle LC, Degiulio PA (1994) Indomethacin-sensitive $\mathrm{CO}_{2}$ reactivity of cerebral arterioles is restored by vasodilator prostaglandin. J Physiol 266: H1332-H1338. Medline

Wagerle LC, Mishra OP (1988) Mechanism of $\mathrm{CO}_{2}$ response in cerebral arteries of the newborn pig: role of phospholipase, cyclooxygenase, and lipoxygenase pathways. Circ Res 62:1019-1026. CrossRef Medline

Zhang C, Rodriguez C, Spaulding J, Aw TY, Feng J (2012) Age-dependent and tissue-related glutathione redox status in a mouse model of Alzheimer's disease. J Alzheimers Dis 28:655-666. CrossRef Medline

Zhang YH, Lu J, Elmquist JK, Saper CB (2003) Specific roles of cyclooxygenase-1 and cyclooxygenase-2 in lipopolysaccharide-induced fever and Fos expression in rat brain. J Comp Neurol 463:3-12. CrossRef Medline

Zhang Y, Chen K, Sloan SA, Bennett ML, Scholze AR, O'Keeffe S, Phatnani HP, Guarnieri P, Caneda C, Ruderisch N, Deng S, Liddelow SA, Zhang C, Daneman R, Maniatis T, Barres BA, Wu JQ (2014) An RNA-sequencing transcriptome and splicing database of glia, neurons, and vascular cells of the cerebral cortex. J Neurosci 34:11929-11947. CrossRef Medline

Zonta M, Angulo MC, Gobbo S, Rosengarten B, Hossmann KA, Pozzan T, Carmignoto G (2003) Neuron-to-astrocyte signaling is central to the dynamic control of brain microcirculation. Nat Neurosci 6:43-50. CrossRef Medline 